Marmara Üniversitesi

İ.̇.B. Dergisi

YIL 2014, CILT XXXVI, SAYI II, S. 185-213

Doi No: 10.14780/iibd.84728

\title{
POLITICAL BUSINESS CYCLES IN THE TURKISH ECONOMY: 1977-2001*
}

\section{Yasemin GEZGIN**}

\section{Abstract}

This study is about political business cycles (PBC) and investigates the Turkish case in the 1977-2001 period. The PBC literature has been developed in the last four-five decades and links economics and politics in several ways.

In the first part of the study, developments in the literature are mentioned and the link between New Classical Economics and New Political Economics is introduced. In the second part, Turkish case is analyzed in details to determine whether there have been PBC during the above mentioned period. The results show that there have been political cycles in some macroeconomic variables which are currency issued, broad money (MI), public sector credits and agricultural credits extended by Central Bank of the Republic of Turkey (CBRT), and tax revenues. CBRT has not allowed PBC especially on the targeted variables (CBRT balance sheet size, net domestic assets and monetary base), after 1989. Due to the high legal ceilings of CBRT credits to the public sector, CBRT was not able to limit those credits, especially before 1991 general elections. There had been similar PBC on agricultural credits which had been extended in the 1977-1991 period by CBRT. In addition to the regression analysis, comparative tables and figures for personnel expenditures of State Economic Enterprises (SEEs), agricultural credits which had been extended by Agricultural Bank of the Republic of Turkey (ABRT) in the 1964-1998 period and agricultural prices which had been declared by governments in the 1986-1999 period are provided in the paper.

The study provides some evidence to PBC literature and determines which policy instruments could have been used to produce PBC in the Turkish economy. And it is also important to learn which policies can be manipulated in order to prevent the $P B C$ in the future.

Keywords: Political business cycles; Autoregression analysis; Time series analysis; Structural breaks; Dummy variables; Turkish economy.

JEL Classification: E5, E6, H2, H3.

This paper was first adapted from Yasemin Kuzu (Gezgin)'s master's thesisat Ankara University by the year 2001 to be submitted to METU Conference in Economics VII in September 6-9, 2003, Ankara and sent to www.econturk.org just after the Conference as a standard procedure. In July 2014, it has been revised in terms of publication rules of Journal of Marmara University Faculty of Economics and Administrative Sciences (Journal of E.A.S.). I would like to thank Fatih Özatay and İrfan Civcir, the advisors of my thesis, for valuable suggestions and help. Any opinions expressed in the paper are those of the author and not those of CBRT.

** Central Bank of Republic of Turkey, yasemin.gezgin@tcmb.gov.tr 


\section{TÜRKIYE EKONOMISINDE POLITIK DEVRESEL HAREKETLER: 1977-2001}

\section{$\ddot{O} z e t$}

Bu çalışma, politik devresel hareketlerle (PDH) ilgili olup, 1977-2001 döneminde Türkiye'de PDH'yi araştırmaktadır. PDH literatürü son 40-50 yılda gelişmiş olup, iktisadı ve politikayı çeşitli yönlerden birbirine bağlamaktadır.

Çalışmanın ilk bölümünde literatürdeki gelişmelere değinilmiş ve Yeni Klasik İktisat ile Yeni Politik İktisat arasındaki bağ tanıtılmıştır. İkinci bölümde, söz konusu dönem için PDH olup olmadığına ilişkin detaylı bir Türkiye analizi yer almaktadır. Sonuçlara göre emisyon, dar anlamda para arzı (M1), Merkez Bankası'nca verilen kamu sektörü kredileri ve tarımsal krediler, vergi gelirleri gibi bazı makro değişkenlerde PDH bulunmaktadır. Bununla birlikte, Merkez Bankası 1989'dan itibaren özellikle hedef değişkenlerde (TCMB bilanço büyüklüğü, net yurt içi varlıklar, parasal taban)PDH'ye izin vermemiştir. Merkez bankasının kamu sektörüne yönelik kredilerindeki yüksek yasal tavanlar dolayısıyla özellikle 1991 genel seçimlerine kadar Merkez Bankası, bu kredilere sınırlandırma getirememiştir. Benzer PDH 1977-1991 döneminde açılan tarımsal kredilerde de yaşanmıştır. Çalışmada regresyon analizine ek olarak, Kamu İktisadi Kuruluşlarının personel harcamalarının, Türkiye Cumhuriyeti Ziraat Bankası'nca 1964-1998 döneminde açılan tarımsal krediler, 1986-1999 döneminde hükümetlerce açıklanan tarımsal fiyatlara ilişkin karşılaştırmalı tablo ve figürler de yer almaktadır.

Çalışma PDH literatürüne bir miktar katkı sağlamakta ve Türkiye ekonomisinde PDH'ye neden olabilecek politika araçlarını belirlemektedir. Ayrıca, seçim öncesinde hangi politikaların manipüle edilebileceğini öğrenmek, gelecekte PDH yaşanmasını önlemek için önemli görünmektedir.

Anahtar Kelimeler: Politik devresel hareketler; otoregresyon analizi; zaman serisi analizi; yapısal kırılmalar; kukla değişkenler; Türkiye ekonomisi.

JEL Sınıflaması: E5, E6, H2, H3.

\section{Introduction}

During the period in which Classical Economics had been a dominant school in economics, it had been a neglected issue that political institutions could affect economic policies. Until the 1960s, sciences of politics and economics had different lines of research. Political scientists had produced normative theories without using any economic tools and concepts, while economists were studying with mathematical tools without trying to understand the effect of political institutions on the economy. After 1960s, economists have been searching for the interaction between politics and 
macroeconomics. When constructing theoretical models usually depended on utility maximization, they accept voters and governments as economic agents maximizing their individual utilities. Thus, as a sub-discipline of political economics "New Political Economics" has been emerged. Since the last three decades, there have been many studies in this line of research. In these studies, political institutions have not been accepted as exogenous variables to macroeconomic policies. On the contrary, they have been considered as endogenously determined by the macroeconomic policies.

Since 1970s, new macroeconomic approaches which take into account, for example, the importance of "credibility problem" (Kydland and Prescott, 1977), the possible effects of general elections ("Political Business Cycles" by Nordhaus, 1975 and "Partisan Theory" by Hibbs, 1977) in applying macroeconomic policies have been developed ${ }^{1}, 2,3$.

Nordhaus and Hibbs' models are the pioneer works of PBC literature which emphasizes the link between political institutions and macroeconomic policies. The main point in both studies is that, the incumbent government manipulates the economy to have the maximum number of votes to be re-elected, and this manipulation in turn causes the economy to fluctuate around its long-run path. A political business cycle is therefore the economy's fluctuation around its long-run behaviour generated by the political system ${ }^{4}$. In other words, the PBC literature studies how interest groups and political pressures within a country influence its macroeconomic performance.

PBC theories, which have been developed in the last three decades, can be classified into two major groups. First classification can be regarded as "first and second generation models", and the second one 'opportunistic and partisan models'.

According to the first classification, the first generation models by Nordhaus and Hibbs can be regarded as "Keynesian models", while the second generation theories by Alesina, Rogoff and Sibert, Persson and Tabellini, Alesina et al. can be regarded as "New Classical Theories".

1 F. Kydlandand E.Prescott (1977), "Rules Rather than Discretion: The Inconsistency of Optimal Plans, Journal of Political Economy, 85, 473-90.

2 W. Nordhaus (1975), "The Political Business Cycle”, The Review of Economic Studies, $42,169-191$.

3 D.Hibbs (1977), "Political Parties and Macroeconomic Policy", American Political Science Review, 71, 1466-1487.

4 M. Paldman (1997), "Political Business Cycles”, in Mueller 1997 (ed.) Perspectives of Public Choice.

5 A. Alesina (1987), "Macroeconomic Policy in a Two-Party System as a Repeated Game", Quarterly Journal of Economics, 102, 650-678; A. Alesina, Cohen, G.D. and Roubini, N. (1992), "Macroecomic Policy and Elections in OECD Democracies. Centre for Economic Policy Research, Discussion Paper No. 608; A. Alesina, Cohen, G.D. and Roubini, N. (1997), Political Cycles and the Macroeconomy, Cambridge, Mass. (USA): The MIT Press; K. Rogoff and Sibert, A. (1988), "Elections and Macroeconomic Policy Cycles", Review of Economic Studies, 55, 1-16; T. Persson and Tabellini, G. (1990), Macroeconomic Policy, Credibility and Politics, New York: Harwood Academic Publishers. 
Based on the second classification, there have been opportunistic and partisan theories including different approaches on the behaviour of governments. Nordhaus' theory depends on a Downsian approach. As discussed by Downs, each politician prefers to be in office rather than out of office ${ }^{6}$. Indeed, the idea that political parties apply policies only to win elections, not for political reasons, first occured by Schumpeter $^{7}$. After 15 years, Downs with 'median voter theorem' made it theoretical based by Olters ${ }^{8}$. Downs' study has been accepted as a classical reference about opportunistic PBC models by Alesina et al. ${ }^{9}$.

Nordhaus discusses that, in a democracy, governments fight against inflation and unemployment to compete with the other parties before elections. Nordhaus' model is a dynamic optimization model applying maximization criteria. 'Phillips Curve', including a trade off mechanism between unemployment and inflation rates and 'Voting function', are the most important components of the model ${ }^{10}$. According to his theory with myopic voters assumption, governments try to convince voters by creating rapid economic growth and slow growth of unemployment rate with monetary and financial policies which trigger aggregate demand. Inflationary results of these policies occur with a lag. After winning elections, tight policies are applied to decrease inflation.

On the other part, Hibbs argues that, left and right wing parties have different objectives to win elections. Left-wing parties are more interested in unemployment and growth, while right-wing parties are more concerned with inflation.

PBC literature, by the pioneered works of Nordhaus and Hibbs, has not been as attractive as it has been since the 1990s. By New Classical second generation versions of PBC theories with 'Rational Expectations' assumption in the 1990s, the literature has become one of the most popular lines of research in political macroeconomics. Alesina developed 'Rational Partisan Theory' following Hibbs' 'Partisan Theory', Persson and Tabellini developed 'Rational PBC' following Nordhaus' PBC theory with 'Rational Expectations' assumption. Thus, second generation models emerged $^{11},{ }^{12},{ }^{13}$.

Following the above mentioned studies, since the mid-seventies political economists have tried to explain the interaction between political and macroeconomic

\footnotetext{
6 A. Downs (1957), An Economic Theory of Democracy, New York: Harper \& Row.

7 J. Schumpeter (1945), Capitalism and Democracy, New York: Harper, 1945.

8 J.P. Olters (2001), "Modeling Politics with Economic Tools: A Critical Survey of the Literature", IMF Working Papers, WP/01/10.

9 Alesina et al., 1997. Ibid.

10 For detailed information about 'Phillips Curve', see the well known paper by Phillips (1958).

11 For the original 'Rational Expectations Theorem”, see Muth (1961).

12 Alesina 1987, Ibid.

13 Persson and Tabellini, Ibid.
} 
variables in the general elections (see for example, Berger and Voitek; Pitruzello; Treisman and Gimpelson; Leertouwer and Maier; Hallerberg and Souza; Cameron and Crosby, Lockwood et al.; Block ${ }^{14}$.

In Turkey also, there have been some studies on the PBC literature since 1999 (see for example, Eren and Bildirici; Özatay; Yamak and Yamak 1999; Tutar and Tansel; Ergun; Telatar and Kuzu) ${ }^{15}$.

It is important to determine which policy instruments could have been used to produce $\mathrm{PBC}$ in the economy, in order to prevent the occurrence of $\mathrm{PBC}$ in the future. By eliminating $\mathrm{PBC}$ from economic variables, macroeconomic efficiency and stabilization in the countries can be improved. The objective of the paper is to determine which policy instruments that could have been used to produce PBC in Turkey in the last decades. Did incumbent governments try to manipulate fiscal and monetary policy instruments so as to get re-elected and stay in office in Turkey? To find an answer

14 H. Berger and Woitek, U. (1997), "Searching for Political Business Cycles in Germany", Public Choice, 91, 2, 179-97; Berger, H. and Woitek, U. (1999), Further Observations on the Political Business Cycle in German Monetary Aggregates, CES, University of Munich and University of Glasgow; Berger, H. and Woitek, U., (2001), "The German political business cycle: money demand rather than monetary policy" European Journal of Political Economy 17, 3, 609-631; S. Pitruzello, (1999), "Political Business Cycles and Independent Central Banks. German Governments and the Bundesbank (1960-1989), EUI Working Paper RSC No. 99/7; D. Treisman and Gimpelson, V. (1999), "Political Business Cycles and Russian Elections, or the Manipulations of 'Chudar", CIRJE-F-39; E. Leertouwer and Maier, P. (2001), "Who creates political business cycles: should central banks be blamed?", European Journal of Political Economy, 17, 3, 445-463; M. Hallerberg and Souza, L. V. (2000), "The Political Business Cycles of EU Accession Countries”, Tinbergen Institute Discussion Paper, TI 2000-085/2; L. Cameron and Crosby, M. (2000), "It's the Economy Stupid: Macroeconomics and Federal Elections in Australia", The Economic Record, Vol. 76, No. 235, (354-364); B., Lockwood, Philippopoulos, A. and Tzavalis, E., (2001) "Fiscal policy and politics: theory and evidence from Greece 1960-1997”, Economic Modelling, 18, 2, 253-268; S. Block A. (2002), Political Business Cycles, Democratization, and Economic Reform: The Case of Africa, Journal of Development Economics, 67, 1, 205-228.

15 Eren, E. and Bildirici, M. (1999), "Siyasal Konjonktür Dalgaları ve Türkiye'de Seçmen Davranış1". İktisat, İşletme ve Finans Dergisi, Ekim, 27-37; Özatay, F. (1999), "Populist Policies and the Role of Economic Institutions in the Performance of Turkish Economy", Yapı Kredi Economic Review, 10, 1; Özatay, F. (2000), Public Price Controls, Deficit Financing, and Electoral Cycles, A Paper Presented at METU Conference in Economics in Sept. 13-16; Yamak, N. and Yamak, R. (1999), "Türkiye'de Genel Milletvekili Seçimleri ve Ekonomi”, İktisat, İşletme ve Finans Dergisi, Şubat, 47-57; Tutar, İ. and Tansel, A. (2000), Political Business Cycles, Institutional Structure and Budget Deficits in Turkey, A Paper Presented at METU Conference in Economics in September 13-16, 2000; Ergun, M. (2000), Electoral Political Business Cycles in Turkey, Thesis (Master's) Bilkent University; Telatar, F. (2001), "Politik Devresel Dalgalanmalar Teorisi Ișı ğında Demokrasi-Siyaset-Ekonomi İlişkisi”, İktisat, İşletme ve Finans, 16, 187, 57-66; Kuzu, Y. (2001), Türkiye Ekonomisinde Politik Devresel Hareketler, Yüksek Lisans Tezi, Ankara Üniversitesi Sosyal Bilimler Enstitüsü. 
to this question, some monetary, finance policy data are regressed and agricultural policies are analyzed.

The remaining of the paper is organized as follows. In the second part, there are some explanations about the methods applied in the empirical analysis of the Turkish case for PBC theory in monetary, fiscal and agricultural policies. The estimation results of the equations and interpretations of the comparative tables are discussed in the third part. And the study concludes with the fourth section.

\section{Methodology}

Autoregressions, comparative tables and figures are used to analyze $\mathrm{PBC}$ in several data. First, specification of the empirical tests are mentioned and then, comparative tables and figures are presented below.

\subsection{Specification of Empirical Tests}

The simplest and most direct way of testing the various economic theories is to run regressions of time-series data (Alesina et al., 1997).

Many economic theories have natural representations as stochastic difference equations. It is one of the most convenience way of modelling dynamic economic processes. Linear difference equations underly much of the theory of time-series econometrics. Especially one important methodology is Box-Jenkins (1976) methodology for estimating time-series models of the form:

$y_{t}=\alpha_{0}+\alpha_{1} y_{t-1}+\ldots+\alpha_{p} y_{t-p}+\beta_{0} \varepsilon_{t}+\beta_{1} \varepsilon_{t-1}+\ldots+\beta_{q} \varepsilon_{t-q}$

where $y t$ is a certain variable on day $t$ and $\varepsilon t$ is a random disturbance term that has an expected value of zero.

Such models are called autoregressive integrated moving average (ARIMA) time series models (Enders, 1995).

Based on the linear difference equations of time-series econometrics as mentioned above, to analyze PBC theory on the Turkish monetary and fiscal policy data, Alesina et al. (1992)'s methodology is applied. In this method, different lag lengths of the dependent variables and election dummies are used as explanatory variables. Here in this study, structural break dummies are also included as explanatory variables to the regressions. In the appendix B, some explanations about these dummy variables are provided.

Thus, general representation of the models used in this study can be defined in the following form:

$m_{t}=\beta_{0}+\beta_{1} m_{t-1}+\beta_{2} m_{t-2}+\ldots .+\beta_{n} m_{t-n}+\beta_{n+1} K_{t}+\dot{\varepsilon}_{t}$

where $\mathrm{mt}$ is the annual growth rate of the data defined as: 
$m_{t}=\left(\left(R M 1_{t}-R M 1_{t-4}\right) / R M 1_{t-4}\right)(100)$ where $R M 1$ is the level of the real variables which are provided in the appendix $\mathrm{C}$ and $\mathrm{K}_{\mathrm{t}}$ is the dummy variable (or variables) appropriate for the related model.

\subsection{Data}

Annual, quarterly and monthly data without seasonally adjustment are used throughout the study. Periods analyzed for each data are changing. For monetary policy analysis, the periods are longer. All data and the related periods analyzed are provided in the appendix A.

\subsection{Election Dummy Variables and Structural Break Dummies}

To determine the effects of elections on the related data, dummy variables are included in the regressions. 'Composite election dummy' that takes a value of one for each election year and 'special election dummy' that takes a value of one for only the special election year are used.

In addition to political dummies, structural break dummies for eliminating the effects of the structural break and external economic shocks from the data are included in the regressions. Conventional approach to structural breaks was that, the effects of external shocks to the economic data would be diminishing and in the long run, data would be stationary. However, Nelson and Plosser has changed this point of view ${ }^{16}$. They found structural breaks in 13 of 14 macroeconomic series. Perron, Zivot and Andrews took attention to the possible misleading effects of structural breaks through the unit root tests ${ }^{17}$. It is a controversial subject whether structural breaks should be taken as exogenous variable or should be determined internally as Perron, ivot and Andrews respectively.

In this study Perron's methodology is adopted and structural breaks are taken as exogenous variables. The related structural break dummy variables are included in all unit root tests and election regressions.

\subsection{Stationarity Tests}

Since all of the series are seasonally unadjusted, possible seasonal unit roots are investigated. The results of the stationarity tests are provided in the appendix $\mathrm{D}^{18}$..

16 C.R. Nelson and Plosser, C.I. (1982), "Trends and Random Walks in Macroeconomic Time Series: Some Evidence and Implications, Journal of Monetary Economics, 10, 139-162.

17 Perron, P. (1989), "The Great Crash, the Oil Price Shock, and the Unit Root Hypothesis, Econometrica, 57, 1361-1401; Zivot, E. and Andrews, D. (1992), "Further Evidence on the Great Crash, the Oil Price Shock and the Unit Root Hypothesis, Journal of Business and Economics Statistics, 10, 251-270.

18 After the study of Nelson and Plosser (1982), there have been arguments about dynamic properties of macroeconomic and financial time series. Stochastic processes may not be stationary and contain unit root problem. In this situation, these processes can not be evaluated by standard statistics theorem. That is why, macroeconomic series should pass through stationarity tests. This is a standard process in econometrics. 
For analyzing unit root problem, Augmented Dickey Fuller (ADF) Test is applied in this paper. In ADF tests, under mentioned regression is applied to each data analyzed.

$\Delta \mathrm{y}_{\mathrm{t}}=\mathrm{a}_{0}+\gamma \mathrm{y}_{\mathrm{t}-1}+\mathrm{a}_{2} \tau+\sum_{\mathrm{i}=2} \mathrm{p}_{\mathrm{i}} \mathrm{y}_{\mathrm{t}-\mathrm{i}+1}+\mathrm{Dz}+\varepsilon_{\mathrm{t}}$

where $\Delta y_{t}$ is the first difference of $y t$, and Dz is structural break and external shock dummy variable ${ }^{19}$.

On Ordinary Least Squares (OLS) estimation results, hypothesis below are tested:

$\mathrm{H}_{0}: \gamma=0\left(\left\{\mathrm{y}_{\mathrm{t}}\right\}\right.$ process contains unit root problem, series is non-stationary).

$\mathrm{H}_{1}: \gamma<1$ ( $\left\{\mathrm{y}_{\mathrm{t}}\right\}$ process does not contains unit root, series is stationary).

In determining the number of lags in the ADF regressions, Weber (2001)'s No Autocorrelation (NAC) method is adopted. For the NAC, autocorrelation up to order four in the residuals of the ADF regression is tested using the Lagrange Multiplier (LM) test. $K$ is set at the smallest value such that the LM test fails to reject the hypothesis of no autocorrelation at the 0.10 level of significance.

According to the ADF regressions' results, the series in levels are non-stationary but their annual growth rates are stationary. That is why annual growth rates of the variables are included in the models.

\section{Estimation Results and Implications}

For the lag length selection in the autoregressions, Campbell and Perron's 'General to Specific Criteria (GSC)' is chosen ${ }^{20}{ }^{21}$. Based on this criteria, regressions in the most general form with maximum lag length, structural break and external shock dummies are estimated first and then the final specific forms of the regressions without residual autocorrelation are reached $22,{ }^{23},{ }^{24}$.

19 From D80, D89, D94 or D98 dummies, appropriate ones for the related period analyzed in the regression dummies are included in the ADF regressions.

20 In their broad overview of the literature on unit root econometrics, Campbell and Perron claimed "GSC" as an appropriate procedure for setting the lag length in ADF regressions.

21 J.Y.Campbell and Perron, P. (1991), "Pittfalls and Opportunities: What Macroeconomists Should Know About Unit Roots", National Bureau of Economic Research, Technical Working Paper No: 100.

22 For the importance of structural breaks in unit root tests' reliability, see Perron (1989), Zivot and Andrews (1992).

23 Maximum lag length is taken according to the Perron (1989), Zivot and Andrews (1992), Hall (1994) as $k m a x=12$ for quarterly data and $k \max =24$ for monthly data as mentioned in Weber (2001).

24 For the importance of structural breaks in unit root tests' reliability, see Perron (1989), Zivot and Andrews (1992). 
Estimation results by OLS are reported in Table 3.1-6, Table 3.2.1-3 and Table 3.3. Absolute t-ratio for each estimated coefficient is defined as $t_{i} \cdot R^{2}$ is the adjusted coefficient of determination. SE is the standard error of the regression. LM is the 'Lagrange Multiplier test' for residual autocorrelation up to order four. ARCH is the autoregressive conditional heteroscedasticity. The null hypothesis of normally distributed residuals is tested by Jarque Bera statistics (JB).

\subsection{Evidence of PBC Theory in Monetary Policies}

The economic data on the PBC analysis in the Turkish monetary policies during the related period are quarterly time-series data of targeted variables by CBRT (CBRT balance sheet size, net domestic assets and monetary base), some other monetary data such as currecy issued and M1, and also public sector credits extended by CBRT. The political data are the election dates. Table 3.1 reports the results of the dynamic OLS regressions.

\section{Table 3.1. Estimation Results of Monetary Policy Equations}

\section{Growth rate of quarterly real CBRT balance sheet size (Grrealbsq)}

Grrealbsq $=2.59+0.86$ Grrealbsq $(-1)+0.51$ Grrealbsq(-4) -0.58 Grrealbsq( $(-5)+$ 0.27 Grrealbsq(-7) - 17.78 D94 - 13.27 D77o3 - 1.37 D77s3

$\mathrm{t}_{1}=2.11, \mathrm{t}_{2}=8.36, \mathrm{t}_{3}=-3,29, \mathrm{t}_{4}=3.81, \mathrm{t}_{5}=-2.49, \mathrm{t}_{6}=-1.74, \mathrm{t}_{7}=-1.70, \mathrm{t}_{8}=0.20$

$\mathrm{R}^{2}=0.58, \mathrm{SE}=9.97$, Sample: $1976 . \mathrm{IV}-2001 . \mathrm{I} \mathrm{LM}=2.55$, $\mathrm{JB}=3521.64, \mathrm{ARCH}=1.25$.

\section{Growth rate of quarterly real currency issued (Grrealciq)}

Grrealciq $=-3.11+0.68$ Grrealciq(-1) -0.61 Grrealciq(-4) + 0.36 Grrealciq( $(-5)-$ 0.21 Grrealciq(-7) + 6.35 Db6 + 5.64 Da6

$\mathrm{t}_{1}=-1.65, \mathrm{t}_{2}=8.09, \mathrm{t}_{3}=-6.23, \mathrm{t}_{4}=3.43, \mathrm{t}_{5}=-2.54, \mathrm{t}_{6}=2.34, \mathrm{t}_{7}=2.16 \mathrm{R}^{2}=0.57$, $\mathrm{SE}=9.19$, Sample: 1979.IV - 2001.I

$\mathrm{LM}=6.84, \mathrm{JB}=11.79, \mathrm{ARCH}=0.65$.

\section{Growth rate of quarterly real broad money supply (Grrealm1q)}

Grrealm1q $=0.03+0.82$ Grrealm1q(-1)-0.55 Grrealm1q(-4) + 0.31 Grrealm1q(-5) 0.23 Grrealm1q(-8) - 18.59 D99o1 +6.20 D99s1

$\mathrm{t}_{1}=0.03, \mathrm{t}_{2}=11.45, \mathrm{t}_{3}=-4.89, \mathrm{t}_{4}=2.7, \mathrm{t}_{5}=-3.03, \mathrm{t}_{6}=2.01, \mathrm{t}_{7}=0.69$

$\mathrm{R}^{2}=0.68, \mathrm{SE}=8.78$, Sample: $1980: \mathrm{I}-2001: \mathrm{I}$

$\mathrm{LM}=8.20$ (0.08), JB = 0.43 (0.81), $\mathrm{ARCH}=4.14$ (0.38). 


\section{Growth rate of quarterly real monetary base (Grrealmbq)}

Grrealmbq $=-1.76+0.77 \operatorname{Grrealmbq}(-1)-0.65$ Grrealmbq(-2) + 0.83 Grrealmbq(-3) 1.19 Grrealmbq(-4) + 1.03 Grrealmbq(-5) - 0.68 Grrealmbq(-6) + 0.55 Grrealmbq(-7) - 1.17 Grrealmbq(-8) + 0.94 Grrealmbq(-9) - 0.61 Grrealmbq(-10) + 0.62 Grrealmbq(-11) - 0.41 Grrealmbq(-12) - 7.93 D89 + 5.49 Db6 + 5.89 Da6

$\mathrm{t}_{1}=-0.40, \mathrm{t}_{2}=5.89, \mathrm{t}_{3}=-4.08, \mathrm{t}_{4}=4.94, \mathrm{t}_{5}=-6.57, \mathrm{t}_{6}=5, \mathrm{t}_{7}=-2.72$,

$\mathrm{t}_{8}=1.90, \mathrm{t}_{9}=-4.45, \mathrm{t}_{10}=3.84, \mathrm{t}_{11}=2.34, \mathrm{t}_{12}=2.21, \mathrm{t}_{13}=-2.05$,

$\mathrm{t}_{14}=-1.68, \mathrm{t}_{15}=1.06, \mathrm{t}_{16}=1.06$

$\mathrm{R}^{2}=0.64, \mathrm{DW}=2.1, \mathrm{SE}=17.09$, Sample: $1981 . \mathrm{I}-1999 . \mathrm{IV} \mathrm{LM}=2.55, \mathrm{JB}=2.34$, $\mathrm{ARCH}=1.25$.

\section{Growth rate of quarterly real net domestic assets (Grrealndaq)}

Grrealndaq $=63.98-0.46$ Grrealndaq $(-1)+194.07$ seas(3) -1231.03 D9899

$\mathrm{t}_{1}=0.91, \mathrm{t}_{2}=-4.51, \mathrm{t}_{3}=-2.23, \mathrm{t}_{4}=-6.34$

$\mathrm{R}^{2}=0.34, \mathrm{SE}=360.36$, Sample: $1978 . \mathrm{II}-2001 . \mathrm{I} \mathrm{LM}=26.67$,

$\mathrm{JB}=7096.25, \mathrm{ARCH}=2.20$.

\section{Growth rate of quarterly real public sector credits (Grrealpscq)}

Grrealpscq $=-1.90+0.96$ Grrealpscq $(-1)-0.44$ Grrealpscq $(-4)$

+ 0.28 Grrealpscq (-5) - 95.68 D94 + 23.72 Db1 + 18.14 Da1

$\mathrm{t}_{1}=-0.59, \mathrm{t}_{2}=13.66, \mathrm{t}_{3}=-3.96, \mathrm{t}_{4}=2.65, \mathrm{t}_{5}=-3.49, \mathrm{t}_{6}=1.72, \mathrm{t}_{7}=1.30 \mathrm{R}^{2}=0.74$, $\mathrm{SE}=26.61$, Sample: $1980 . \mathrm{II}-1998 . \mathrm{IV}$

$\mathrm{LM}=3.72, \mathrm{JB}=13.46, \mathrm{ARCH}=21.99$.

The specific forms of equations above are regressed for each pairs of the election dummies such as before election dummies and after election dummies provided in Table E1-E6, appendix E. The signs of the coefficients are as expected apriori. According to the t-values of the election dummies, it can be concluded that there have been no PBC in the targeted variables of the monetary policy during the period analy$\mathrm{zed}^{25}$. Indeed, the fifth model above for Grrealndaq is out of consideration because of its low R2 value. However, based on the line graph of Grrealndaq following a stable path, it can be concluded that CBRT did not allow PBC occurrence in the Realndaq (see appendix F).

25 In Turkey, after institutional reforms realized in the 1980s, CBRT's monetary policy tools has been diversified. Before 1980, currency issued, which is an important percentage of CBRT balance sheet size, had been used as a monetary indicator for CBRT's monetary policies. After 1980, reserve money, monetary base, central bank money, M series (M1, M2, M2Y, M3Y) have been used as monetary indicators (Öztürk, 1992).

The first monetary programme of CBRT " 1990 Monetary Programme" and the second one "1992 Monetary Programme" determine monetary indicators of CBRT monetary policies as follows: Net Domestic Assets, Sum of Domestic Liabilities, CBRT Balance Sheet Size, Central Bank Money (Ersel and Öztürk, 1992). 
Although there have been no PBC in the targeted variables, there has been some evidence of PBC on the currency issued, M1 and public sector credits data. For example, ceteris paribus, based on the $t$-values and coefficients of composite dummy variables in the Tables E.2-3, five - six quarters before elections, annual growth rates of currency issued and M1 had been almost four - six percent higher than those of other periods.

\subsection{Evidence of PBC in Finance Policies}

In testing PBC theory in the Turkish finance policies from the late 1980 s to the end of 2000, monthly time-series data of growth rate of monthly public expenditures, real public personnel expenditures, real tax revenues are regressed. The results of the equations are provided below.

\section{Table 3.2. Estimation Results of Finance Policy Equations}

\section{Growth rate of monthly public expenditures (with constant prices) (Grrealpe)}

Grrealpe $=0.90+0.94$ Grrealpe $(-1)-0.32$ Grrealpe $(-3)+0.32$ Grrealpe $(-4)-0.19$ Grrealpe(-6) + 0.17 Grrealpe(-7) - 0.17 Grrealpe(-12)

+0.14 Grrealpe(-13) + 0.17 Grrealpe(-15) - 0.17 Grrealpe(-16)

+0.19 Grrealpe(-18) - 0.21 Grrealpe(-19) + 0.14 Grrealpe(-21)

- 0.18 Grrealpe(-22) - 35.21 D94 - 1.07 Db6 + 0.54 Da6

$\mathrm{t}_{1}=0.92, \mathrm{t}_{2}=14.76, \mathrm{t}_{3}=-3.14, \mathrm{t} 4=3.09, \mathrm{t}_{5}=-1.92, \mathrm{t}_{6}=1.93, \mathrm{t}_{7}=-2.66$,

$\mathrm{t}_{8}=1.85, \mathrm{t}_{9}=2.15, \mathrm{t}_{10}=-2.06, \mathrm{t}_{11}=2.23, \mathrm{t}_{12}=-2.43, \mathrm{t}_{13}=1.82, \mathrm{t}_{14}=-2.67, \mathrm{t}_{15}=-3.63$, $\mathrm{t}_{16}=0.42, \mathrm{t}_{17}=0.22$

$\mathrm{R}^{2}=0.83, \mathrm{SE}=9.11$, Sample: 1989.XI $-2000 . \mathrm{XII} \mathrm{LM}=12.69$, $\mathrm{JB}=297.86, \mathrm{ARCH}=13.09$.

\section{Growth rate of monthly real public personnel expenditures (Grrealppe)}

Grrealppe $=1.68+0.96$ Grrealppe $(-1)-0.36$ Grrealppe $(-12)$

+ 0.29 Grrealppe(-13) - 19.50 D94 + 0.74 Db6 - 1.39 Da6

$\mathrm{t}_{1}=1.86, \mathrm{t}_{2}=38.06, \mathrm{t}_{3}=-4.68, \mathrm{t}_{4}=3.82, \mathrm{t}_{5}=-2.52, \mathrm{t}_{6}=0.43, \mathrm{t}_{7}=-0.79 \mathrm{R}^{2}=0.90$, SE $=7.69$, Sample: $1987 . \mathrm{II}-2000 . \mathrm{XII}$

$\mathrm{LM}=18.25, \mathrm{JB}=2184.74, \mathrm{ARCH}=9.83$.

\section{Growth rate of monthly real tax revenues (Grrealtr)}

Grrealtr $=0.87+0.98$ Grrealtr(-1) -0.23 Grrealtr(-2) +0.11 Grrealtr(-6) - 0.52 Grrealtr(-12) + 0.33 Grrealtr(-13) + 0.11 Grrealtr(-18)

+0.21 Grrealtr(-23) - 0.29 Grrealtr(-24) + 3.61 D89 - 25.08 D94 - 3.18 Db6 - 0.85

Da6

$\mathrm{t}_{1}=0.57, \mathrm{t}_{2}=14.27, \mathrm{t}_{3}=-3.42, \mathrm{t}_{4}=2.42, \mathrm{t}_{5}=6.18, \mathrm{t}_{6}=3.81, \mathrm{t}_{7}=2.07, \mathrm{t}_{8}=2.62$,

$\mathrm{t}_{9}=-3.63, \mathrm{t}_{10}=2.26, \mathrm{t}_{11}=-4.84, \mathrm{t}_{12}=-2.35, \mathrm{t}_{13}=-0.67$

$\mathrm{R}^{2}=0.87, \mathrm{SE}=5.12$, Sample: 1988. $\mathrm{I}-2000 . \mathrm{XII} \mathrm{LM}=9.77, \mathrm{JB}=341.26, \mathrm{ARCH}=25.42$. 
According to the estimation results of the finance policy equations, except tax revenue equations, the signs of the coefficients and t-values of election dummies are not as expected apriori. It can be concluded that, there had been no PBC on Grrealpe and Grrealppe during the 1987-2000 period. However, the coefficients and t-values of election dummies of the tax revenue model are as expected and there had been PBC as suggested by Rogoff and Sibert $(1988)^{26}$. They argue that, before elections, growth rate of the real tax revenues are lowered than those of non-election years and after elections, governments increase tax rates to gain more tax revenues. In accordance with the argument above, in Turkey during the 1988-2000 period, ceteris paribus, before election years growth rates of tax revenues had been decreased substantially and after election years, they had been increased considerably. The coefficients and t-values of dummies are provided in the Tables E12-13 in the appendix E.

In addition to the regression analysis, a figure which has a comparison between the series of 'the annual growth rate of public personnel expenditures per-person in SEEs (Grppe)' and 'annual inflation rate (inflation)' is presented below.

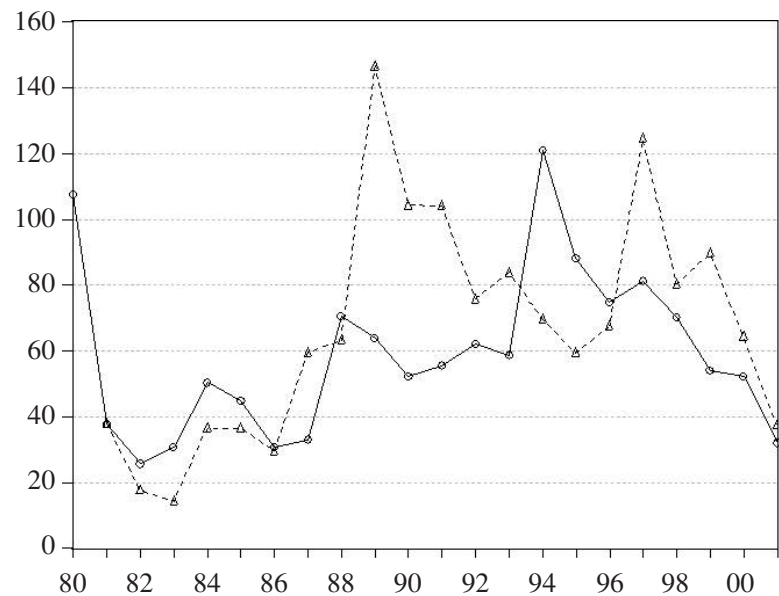

Inflation $-\cdots$ Grppe

Figure 3.1. Relationship between Inflation and Grppe

As can be observed from the Figure 3.1, there had been substantial growth rates which exceed inflation rate in 1987, 1991 and 1999 elections. In 1991 and 1999 elections, values of the series also circulated above the average of the series. It can be concluded from the data that there had been $\mathrm{PBC}$ in public personnel expenditures of SEEs in the period of 1980-2001.

26 K.Rogoff and Sibert, A. (1988), "Elections and Macroeconomic Policy Cycles”, Review of Economic Studies, 55, 1-16 


\subsection{Evidence of $\mathrm{PBC}$ in Agricultural Policies}

CBRT had extended agricultural credits before 1991. In testing the PBC theory on agricultural policies, the series of growth rate of agricultural credits which had been extended by CBRT in the 1977-1991 period are regressed. In addition to the regression analysis, agricultural credits extended by ABRT in the 1965-1999 period, and the relationship between the announcement dates of some subsidized agricultural product prices declared by governments and general election dates are analyzed in terms of PBC theory by comparative tables in this sub-section.

Table 3.3. Estimation results of the growth rate of quarterly real agricultural credits (Grrealacq)

Grrealacq $=1.10+0.65$ Grrealacq $(-1)+0.26$ Grrealacq $(-5)-0.38$ Grrealacq $(-6)+$ $76.42 \mathrm{Db} 1+60.66 \mathrm{Da} 1$

$\mathrm{t}_{1}=0.12, \mathrm{t}_{2}=6.14, \mathrm{t}_{3}=1.83, \mathrm{t}_{4}=-2.70, \mathrm{t}_{5}=2.15, \mathrm{t}_{6}=1.42 \mathrm{R}^{2}=0.60, \mathrm{SE}=58.64$, Sample: 1979.III - 1991.III

$\mathrm{LM}=0.76, \mathrm{JB}=259.65, \mathrm{ARCH}=0.37$.

According to the estimation results of the regression in Table 3.3, there had been PBC especially before election years in the Grreealacq series. Ceteris paribus, one quarter before election date, the growth rate of the credits had been 76.42 percent more than those of non-election terms. For the other t-values and coefficients of the specific election year dummies see Table E7 provided in the appendix E. There is also clear evidence of $\mathrm{PBC}$ on the specific election dummies of 1987 and 1991 elections. 
Table 3.4. Annual growth rate of agricultural credits extended by ABRT (1965-1999) (GRAC)

\begin{tabular}{|c|c|c|c|}
\hline Year & $\operatorname{GRAC}(\%)$ & Avnonel & $\pi$ \\
\hline 1965 & -1 & & 10 \\
\hline 1966 & 63 & & 4 \\
\hline 1967 & 11 & & 6 \\
\hline 1968 & 25 & & 3 \\
\hline 1969 & $8 *$ & 25 & 6 \\
\hline 1970 & -4 & & 6 \\
\hline 1971 & -5 & & 17 \\
\hline 1972 & 58 & & 18 \\
\hline 1973 & $66 * * *$ & 16 & 20 \\
\hline 1974 & 40 & & 30 \\
\hline 1975 & 62 & & 11 \\
\hline 1976 & 7 & & 16 \\
\hline 1977 & 21 & 36 & 24 \\
\hline 1978 & 35 & & 50 \\
\hline 1979 & 86 & & 65 \\
\hline 1980 & 55 & & 107 \\
\hline 1981 & 44 & & 38 \\
\hline 1982 & -14 & & 26 \\
\hline 1983 & $46 * * *$ & 42 & 30 \\
\hline 1984 & 33 & & 51 \\
\hline 1985 & 55 & & 40 \\
\hline 1986 & 96 & & 27 \\
\hline 1987 & 40 & 61 & 40 \\
\hline 1988 & 24 & & 37 \\
\hline 1989 & 68 & & 105 \\
\hline 1990 & 43 & & 52 \\
\hline 1991 & $73 * * *$ & 45 & 55 \\
\hline 1992 & 90 & & 62 \\
\hline 1993 & 84 & & 59 \\
\hline 1994 & 36 & & 121 \\
\hline 1995 & $224 * * *$ & 70 & 88 \\
\hline 1996 & 40 & & 75 \\
\hline 1997 & 95 & & 81 \\
\hline 1998 & 178 & & 70 \\
\hline Average & 52 & & \\
\hline
\end{tabular}

Source: State Statistics Institute (SSI) “Agricultural Statistics, 1923-1998”, (2001) Avnonel: Average of non-election years before the election year

$\pi$ : Annual inflation ratio

*** : GRAC exceeds $\pi$, Avnonel and average of the series

** : GRAC exceeds two of $\pi$, Avnonel or average of the series

* : GRAC exceeds one of $\pi$, Avnonel or average of the series years characterized in bold letters are the election years. 
Based on the values provided by Table 3.4, GRAC exceeds $\pi$ during the five $(1969,1973,1983,1991,1995)$ of the seven election years. In 1973, 1983, 1991 and 1995 elections, GRAC exceeds both $\pi$, Avnonel and average of the series.

Table 3.5. Relationship between announcement dates of subsidized prices of some agricultural products declared by governments and the general election dates

\begin{tabular}{|c|c|c|c|c|c|}
\hline $\begin{array}{l}\text { Subsidized } \\
\text { agricultural } \\
\text { products }\end{array}$ & $\begin{array}{l}\text { Date of } \\
\text { announcement } \\
\text { by Council of } \\
\text { Ministers }\end{array}$ & $\begin{array}{l}\text { General } \\
\text { Election } \\
\text { Year }\end{array}$ & $\begin{array}{l}\text { Subsidized } \\
\text { agricultural } \\
\text { products }\end{array}$ & $\begin{array}{l}\text { Date of } \\
\text { announcement } \\
\text { by Council of } \\
\text { Ministers }\end{array}$ & $\begin{array}{l}\text { General } \\
\text { Election } \\
\text { Year }\end{array}$ \\
\hline Tobacco & 20.08 .1986 & \multirow{9}{*}{ 29.11.1987 } & Tobacco & 28.05 .1993 & \multirow{21}{*}{ 24.12.1995 } \\
\hline Cereals & 09.10 .1986 & & Cereals & 28.05 .1993 & \\
\hline Sugar beet & 09.10 .1986 & & Sugar beet & 03.09 .1993 & \\
\hline Tobacco & 27.12 .1987 & & Tobacco & 05.02.1994 & \\
\hline Cereals & 10.12 .1987 & & Cereals & 10.06.1994 & \\
\hline Sugar beet & 02.12 .1987 & & Sugar beet & 02.10 .1994 & \\
\hline Tobacco & - & & Tobacco & 03.05.1995 & \\
\hline Cereals & 31.05 .1988 & & Cereals & 31.08 .1995 & \\
\hline Sugar beet & - & & Sugar beet & 21.10 .1995 & \\
\hline Tobacco & 03.08.1989 & \multirow{12}{*}{20.10 .1991} & Tobacco & 08.05.1996 & \\
\hline Cereals & 18.05 .1989 & & Cereals & 09.06.1996 & \\
\hline Sugar beet & 30.07 .1989 & & Sugar beet & 21.06.1996 & \\
\hline Tobacco & 16.03 .1990 & & Tobacco & 26.11 .1997 & \\
\hline Cereals & 16.05 .1990 & & Cereals & & \\
\hline Sugar beet & 10.03 .1990 & & Sugar beet & 22.03 .1997 & \\
\hline Tobacco & 03.05.1991 & & Tobacco & 28.11.1998 & \\
\hline Cereals & 15.06.1991 & & Cereals & 16.05 .1998 & \\
\hline Sugar beet & 14.08 .1991 & & Sugar beet & 01.10 .1998 & \\
\hline Tobacco & - & & Tobacco & 01.04.1999 & \\
\hline Cereals & 14.07.1992 & & Cereals & 01.07.1999 & \\
\hline Sugar beet & 05.12 .1992 & & Sugar beet & - & \\
\hline
\end{tabular}

According to the Table 3.5, some agricultural products' subsidized prices had been announced only a few months before general election dates except the year 1987 . 
Table 3.6. Growth rates of annual average prices of some subsidized agricultural products during the period of 1965-1998 (GRAP)

\begin{tabular}{|c|c|c|c|c|c|c|c|c|c|c|c|c|c|c|c|c|c|c|c|}
\hline Year & $\frac{\text { ప্ট்: }}{\bar{E}}$ & $\underset{\bar{E}}{\bar{\Xi}}$ & 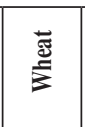 & 离 & 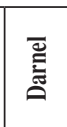 & 总 & है & 总 & $\begin{array}{l}\text { ठ্ّ } \\
\text { है } \\
\text { है }\end{array}$ & 总 & 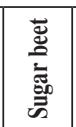 & 㐫 & 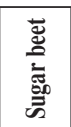 & 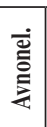 & 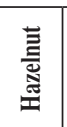 & $\begin{array}{l}\bar{\Xi} \\
\text { 竞 }\end{array}$ & 葋 & 离 & $\pi$ \\
\hline 1965 & 10 & & 4 & & 0 & & $13^{*}$ & & 10 & & - & & - & & - & & - & & 10 \\
\hline 1966 & 4 & & 0 & & 0 & & 4 & & -8 & & - & & - & & -4 & & 0 & & 4 \\
\hline 1967 & -20 & & 0 & & 0 & & 0 & & -2 & & - & & - & & 5 & & 0 & & 6 \\
\hline 1968 & 11 & & 0 & & 0 & & 11 & & 6 & & - & & - & & 0 & & 0 & & 3 \\
\hline 1969 & $12 * *$ & -5 & $3 *$ & 0 & $5^{*}$ & 0 & $6^{*}$ & 5 & $4^{*}$ & -1 & - & & - & & $9 * *$ & 0.3 & 0 & & 6 \\
\hline 1970 & 18 & & 6 & & 8 & & 9 & & -6 & & 21 & & 33 & & 32 & & 23 & & 6 \\
\hline 1971 & 23 & & 16 & & 15 & & 22 & & 8 & & 20 & & 0 & & 13 & & 4 & & 17 \\
\hline 1972 & 0 & & 0 & & -1 & & 0 & & 29 & & 14 & & 0 & & 0 & & 0 & & 18 \\
\hline 1973 & $19 *$ & 14 & $21 * *$ & 7 & $20 *$ & 7 & $21 * *$ & 10 & $13^{*}$ & 10 & $60 * * *$ & 18 & $50 * * *$ & 11 & 14 & 15 & $140 * * *$ & 9 & 20 \\
\hline 1974 & 73 & & 77 & & 76 & & 75 & & 75 & & 33 & & 37 & & 39 & & 43 & & 30 \\
\hline 1975 & 7 & & 10 & & 6 & & 10 & & 35 & & 0 & & 34 & & 4 & & 0 & & 11 \\
\hline 1976 & 6 & & 10 & & 6 & & 6 & & 25 & & 28 & & 18 & & 4 & & 5 & & 16 \\
\hline 1977 & 6 & 29 & 11 & 32 & 7 & 29 & 6 & 30 & 13 & 45 & 5 & 20 & 5 & 30 & 14 & 16 & 14 & 16 & 24 \\
\hline 1978 & 36 & & 12 & & 31 & & 26 & & 13 & & 28 & & 32 & & 30 & & 46 & & 50 \\
\hline 1979 & 75 & & 57 & & 90 & & 92 & & 22 & & 82 & & 58 & & 74 & & 129 & & 65 \\
\hline 1980 & 89 & & 103 & & 80 & & 85 & & 83 & & 100 & & 118 & & 193 & & 113 & & 107 \\
\hline 1981 & 56 & & 83 & & 52 & & 41 & & 24 & & 26 & & 48 & & 14 & & 29 & & 38 \\
\hline 1982 & 12 & & 22 & & 19 & & 17 & & 53 & & 24 & & 28 & & 20 & & 20 & 67 & 26 \\
\hline 1983 & $37 *$ & 54 & 29 & 55 & 16 & 54 & 21 & 52 & $34 *$ & 39 & 22 & 52 & 16 & 57 & 17 & 66 & 20 & & 30 \\
\hline 1984 & 101 & & 58 & & 144 & & 159 & & 34 & & 97 & & 32 & & 44 & & 33 & & 51 \\
\hline 1985 & 20 & & 33 & & 14 & & 14 & & 42 & & 29 & & 56 & & 167 & & 38 & & 40 \\
\hline 1986 & 23 & & 27 & & 25 & & 22 & & 44 & & 23 & & 23 & & 2 & & 38 & & 27 \\
\hline 1987 & 26 & 48 & 22 & 39 & 26 & 61 & 30 & 65 & $87^{* *}$ & 40 & $110^{* *}$ & 50 & 33 & 37 & $73 * *$ & 71 & $43^{* *}$ & 36 & 40 \\
\hline 1988 & 70 & & 71 & & 71 & & 76 & & 101 & & 41 & & 99 & & 70 & & -100 & & 37 \\
\hline 1989 & 99 & & 98 & & 101 & & 80 & & 62 & & 86 & & 85 & & 36 & & - & & 105 \\
\hline 1990 & 44 & & 54 & & 55 & & 67 & & 63 & & 38 & & 69 & & 25 & & - & 52 & -33 \\
\hline 1991 & $61 * *$ & 71 & $50^{*}$ & 74 & 44 & 75 & 41 & 74 & 41 & 75 & $57 * * *$ & 55 & 54 & 84 & $63 * * *$ & 44 & $63^{* * *}$ & 55 & 62 \\
\hline 1992 & 57 & & 53 & & 54 & & 57 & & 137 & & 69 & & 63 & & 72 & & 76 & 59 & 121 \\
\hline 1993 & 63 & & 59 & & 64 & & 28 & & 27 & & 51 & & 56 & & 104 & & 46 & & \\
\hline 1994 & 69 & & 92 & & 82 & & 132 & & 63 & & 180 & & 86 & & 185 & & 106 & & \\
\hline 1995 & $99 * * *$ & 63 & $111 * * *$ & 68 & $97 * * *$ & 67 & $79 * *$ & 72 & $90 * * *$ & 76 & $59 *$ & 100 & $166^{* * * *}$ & 68 & 45 & 120 & $80 * * *$ & 76 & 88 \\
\hline 1996 & 179 & & 197 & & 149 & & 188 & & 86 & & 69 & & 74 & & 152 & & 111 & & 75 \\
\hline 1997 & 69 & & 59 & & 99 & & 91 & & 105 & & 104 & & 154 & & 158 & & 104 & & 81 \\
\hline 1998 & 53 & & 52 & & 54 & & 56 & & 74 & & 30 & & 46 & & 45 & & 59 & & 70 \\
\hline Average & 44 & & 44 & & 44 & & 47 & & 44 & & 52 & & 54 & & 52 & & 41 & & \\
\hline
\end{tabular}

Source: State Statistics Institute (SSI) “Agricultural Statistics, 1923-1998”, (2001) Avnonel: Average of non-election years before the election year

$\pi$ : Annual inflation ratio

*** : GRAP exceeds $\pi$, Avnonel and average of the series

** : GRAP exceeds two of $\pi$, Avnonel or average of the series 
: GRAP exceeds one of $\pi$, Avnonel or average of the series years characterized in bold letters are the election years.

According to the Table 3.6, GRAP of many agricultural products exceeds both $\pi$, Avnonel and average of the series during or before the election year.

\section{Conclusions}

Although the pioneered works of the PBC literature had been developed in the late 1970s as a branch of New Political Economics, the PBC theories have been a popular line of research in the 1990s'. Since it is now a widely accepted issue that political institutions can not be excluded from the analysis of macroeconomic policies, possible effects of political institutions on macroeconomic policies has been researched in several countries.

Following the PBC literature in this paper, possible effects of general elections on the monetary and finance policies and agricultural policies during the last decades in the Turkish economy are investigated. The summary of the results of the analysis are as follows. While CBRT has not allowed PBC occurrence on the targeted variables, there has been some evidence of PBC on some monetary data such as currency issued and M1. In addition, before 1998, CBRT had to extend some public sector credits. Due to the high legal ceilings, CBRT had not been able to limit these credits during the related period. So, there has been clear evidence of PBC on the public sector credits data. After 1998, CBRT has never extended any credits to the public sector. This issue is strictly determined in the CBRT Law No. 1211 which was changed in 25th of April, 2001 with Law no. 4651. According to the changes in the CBRT Law, CBRT will never extend public credits. Since, the results reached in this paper are in favour of PBC theory, it seems an appropriate application for CBRT to become independent.

There has been some evidence of PBC in the finance policies, especially for tax revenues in the 1988-2000 period. Based on the regression results, it can be concluded that, before election years, growth rates of tax revenues had been decreased substantially, and after elections they had been increased considerably in the period analyzed.

Based on the analysis of the agricultural policies, it is determined that, some opportunistic policies had been occurred over the period of 1964-1998 in Turkey. Annual agricultural credits extended by ABRT had been increased substantially before election years. Prices of some subsidized agricultural products had been announced just a few months before the election dates. Annual growth rates of the subsidized agricultural products' prices had been realized higher than those of non- election years before and in the election years. The series of the growth rate of agricultural credits extended by CBRT had followed a similar PBC during the 1977-1991 period. Ceteris paribus, the growth rates of real agricultural credits by CBRT before election years had been higher than those of non-election periods. After 1991, CBRT has never extended agricultural credits. 
It is important to determine which policy instruments could have been used to produce $\mathrm{PBC}$ in the Turkish economy, in order to prevent the occurrence of PBC in the future. In this study, some policy instruments that could have been used to produce $\mathrm{PBC}$ are researched and what can be done to prevent the occurrence of $\mathrm{PBC}$ is left for the future work.

\section{Appendix A: Data}

\section{Quarterly Data:}

CBRT balance sheet size (BS) (1974:I-2001:I), Currency issued (CI) (1977:I-2000:IV),

Broad money supply (M1) (1977:I-2000:IV),

Net domestic assets of CBRT (NDA) (1977:I-2000:IV),

Monetary base (MB) (1977:I-2000:IV),

CBRT credits to public sector (net) (PSC) (1977:I- 1998:IV).

Agricultural credits extended by CBRT (AC) (1977:I-1991:III),

\section{Monthly Data:}

Public expenditures (PE) (1987:01-2000:12),

Tax revenues (TR) (1985:01-2000:12),

Public personnel expenditures (PPE) (1985:01-2000:12).

\section{Annual Data:}

Personnel expenditures of State Economic Enterprises (1985-2001),

Agricultural prices declared by governments (1986-1999).

Agricultural credits extended by ABRT (1965-1998).

\section{General Election Dates in Turkey:}

1965 - October 10, 1965

1969 - October 12, 1969

1973 - October 14, 1973

1977 - June 5, 1977

1980 - September 12, 1980

1983 - November 6, 1983

1987 - October 29, 1987

1991 - October 20, 1991

1995 - December 24, 1995

1999 - April 18, 1999 


\section{Appendix B: Dummy Variables}

\section{Political Dummy Variables}

\section{Composite Election Dummies:}

a) Before election dummies ( $D b n$ ) are dummy variables that take a valueof one in the $\mathrm{n}$ periods before election date. Otherwise, they take a value of zero.

b) After election dummies (Dan) take a value of one in the n periods afterelection date. Otherwise, they take a value of zero.

2.Special Election Dummies (D77bn/an, D83bn/an, D91bnasn, D95bn/an, $D 99 b / a)$ are the dummy variables that take a value of one in the n periods beforeelection date (D..bn), and after election date (D..an).

\section{Structural Break Dummies:}

1. '1980 shock dummy variable (D80)' takes a value of one in the militaryadministration period beginning by 12 th of September in 1980. Otherwise, it takes a value of zero.

2. '1989 structural break dummy variable (D89)' takes a value of one in thefull capital mobility period beginning by August of 1989. Otherwise, it takes a value of zero.

3. '1994 shock dummy variable (D94)', takes a value of one in the 1994Turkish economy crisis period beginning by 5 th of April in 1994. Otherwise, it takes a value of zero.

4. '1998 Russian crisis dummy variable (D98)' takes a value of one in the1998 Russian economy crisis year. Otherwise, it takes a value of zero.

\section{Appendix C: List of Variables}

\section{Level of Variables:}

$\begin{array}{ll}\text { REALACQ } & \text { Quarterly real agricultural credits } \\ \text { REALBSQ } & \text { Quarterly real CBRT balance sheet size } \\ \text { REALCIQ } & \text { Quarterly real currency issued } \\ \text { REALM1Q } & \text { Quarterly real broad money supply } \\ \text { REALMBQ } & \text { Quarterly real monetary base } \\ \text { REALNDAQ } & \text { Quarterly real net domestic assets } \\ \text { REALPE } & \text { Monthly public expenditures (with constant prices) } \\ \text { REALPPE } & \text { Monthly real public personnel expenditures } \\ \text { REALPSC } & \text { Quarterly real public sector credits } \\ \text { REALTE } & \text { Monthly real tax revenues }\end{array}$




\section{Growth of Variables}

GRREALPE Annual growth rate of monthly public expenditures (with constant prices)

GRREALAC Annual growth rate of quarterly real agricultural credits

GRREALBSQ Annual growth rate of quarterly real CBRT balance sheet size

GRREALCIQ Annual growth rate of quarterly real currency issued

GRREALM1Q Annual growth rate of quarterly real broad money supply

GRREALMBQ Annual growth rate of quarterly real monetary base

GRREALNDAQ Annual growth rate of quarterly real net domestic assets

GRREALPPE Annual growth rate of monthly real public personnel ex penditures

GREALPSCQ Annual growth rate of quarterly real public sector credits

GRREALTR Annual growth rate of monthly real tax revenues

\section{Appendix D: $\operatorname{ADF}(K)$ Unit Root Test Results}

Table D1: Level Results

\begin{tabular}{|c|c|c|c|c|}
\hline \multicolumn{5}{|l|}{ LEVEL } \\
\hline VARIABLE & $\mathbf{K}$ & $\mathbf{A}$ & B & $\mathrm{C}$ \\
\hline REALCIQ & 6 & $-3.71 *$ & $-3.11 *$ & $-3.64 * *$ \\
\hline REALM1Q & 8 & -3.51 & -4 & -0.52 \\
\hline REALNDAQ & 1 & -1.87 & -1.07 & -1.21 \\
\hline REALMBQ & 5 & -1.64 & -1.74 & -2.3 \\
\hline REALACQ & 2 & -0.89 & -2.55 & $-3.46^{* *}$ \\
\hline REALPSCQ & 0 & -0.75 & -0.16 & -0.72 \\
\hline REALBSQ & 0 & 1.21 & 1.83 & 1.42 \\
\hline$\% 1$ Critical Values & & -4.06 & -3.51 & -2.59 \\
\hline$\% 5$ Critical Values & & -3.46 & -2.89 & -1.94 \\
\hline REALTE & 24 & 1.72 & 2.78 & 2.12 \\
\hline REALPE & 9 & -1 & -0.89 & -0.6 \\
\hline REALPPE & 12 & -2.68 & -1.99 & -1.39 \\
\hline$\% 1$ Critical Values & & -4.01 & -3.46 & -2.57 \\
\hline$\% 5$ Critical Values & & -3.43 & -2.87 & -1.94 \\
\hline
\end{tabular}

1. $\mathrm{k}$, is the number of lags in ADF regressions. In lag length selection, Weber's No Autocorrelation (NAC) method is applied.

2. Column $\mathrm{A}, \mathrm{B}$ and $\mathrm{C}$ give the t-statistics from $\mathrm{ADF}$ regression including constant and trend, constant and without constant respectively.

3 . The critical values are from MacKinnon ${ }^{27}$. The superscripts $*$ and $* *$ denotes rejection at $5 \%$ and $1 \%$ critical values.

27 J.Mackinnon G. (1991), Critical Values for Cointegration Tests. In: R. F. Engle and C. W. J. Granger (Eds.) Long-run Economic Relationships: Readings in Cointegration, Oxford

University Press, Oxford. pp.267-276. 
Tablo D2: Annual Growth Rate Results

\begin{tabular}{|l|c|c|c|c|}
\hline \multicolumn{6}{|l|}{ ANNUAL GROWTH RATE $(\boldsymbol{\%})$} \\
\hline VARIABLE & K & A & B & C \\
\hline GRREALCIQ & 4 & $-3.79^{*}$ & $-3.78^{* *}$ & $-3.74^{* *}$ \\
GRREALM1Q & 4 & $-3.98^{*}$ & $-3.67^{* *}$ & $-3.62^{* *}$ \\
GRREALNDAQ & 1 & $-7.44^{* *}$ & $-7.11^{* *}$ & $-6.99^{* *}$ \\
GRREALMBQ & 4 & -2.54 & -2.57 & $-2.59^{*}$ \\
GRREALACQ & 0 & -2.97 & -2.67 & $-2.68^{*}$ \\
GRREALPSCQ & 3 & $-3.87 *$ & $-3.76^{* *}$ & $-3.75^{* *}$ \\
GRREALBSQ & 6 & -2.33 & -2.24 & $-2.3 *$ \\
\hline \%1 Critical Values & & -4.06 & -3.51 & -2.59 \\
\%5 Critical Values & & -3.46 & -2.89 & -1.94 \\
\hline GRREALTR & 12 & $-3.61 *$ & $-3.53 * *$ & $-3.94 * *$ \\
GRREALPE & 6 & -3.13 & $-3 *$ & $-3.08^{* *}$ \\
GRREALPPE & 6 & $-4.12^{* *}$ & $-3.62^{* *}$ & $-3.44 * *$ \\
\hline \%1 Critical Values & & -4.01 & -3.46 & -2.57 \\
\%5 Critical Values & & -3.43 & -2.87 & -1.94 \\
\hline
\end{tabular}

1. $\mathrm{k}$, is the number of lags in ADF regressions. In lag length selection, Weber's No Autocorrelation (NAC) method is applied.

2. Column A, B and $\mathrm{C}$ give the t-statistics from ADF regression including constant and trend, constant and without constant respectively.

3. The critical values are from MacKinnon ${ }^{28}$. The superscripts $*$ and $* *$ denotes rejection at $5 \%$ and $1 \%$ critical values. 


\section{Appendix E: Estimation Results for Dummy Variablesxi}

Table E1. Growth rate of quarterly real CBRT balance sheet size

\begin{tabular}{|c|c|c|c|c|c|c|c|c|c|c|c|c|}
\hline Grrealbsq & Db1 & Db2 & Db3 & Db4 & Db5 & Db6 & Da1 & Da2 & Da3 & Da4 & Da5 & Da6 \\
\hline $\begin{array}{c}\text { Composite } \\
\text { dummy }\end{array}$ & $\begin{array}{c}0.24 \\
(0.05)\end{array}$ & $\begin{array}{c}1.35 \\
(0.41)\end{array}$ & $\begin{array}{c}-1.07 \\
(-0.37)\end{array}$ & $\begin{array}{c}-0.83 \\
(-0.31)\end{array}$ & $\begin{array}{c}-1.45 \\
(0.55)\end{array}$ & $\begin{array}{c}-0.61 \\
(-0.22)\end{array}$ & $\begin{array}{c}-1.14 \\
(-0.26)\end{array}$ & $\begin{array}{c}0.85 \\
(0.26)\end{array}$ & $\begin{array}{c}0.45 \\
(0.16)\end{array}$ & $\begin{array}{c}-0.86 \\
(-0.33)\end{array}$ & $\begin{array}{c}-2.07 \\
(-0.81)\end{array}$ & $\begin{array}{c}-2.80 \\
(-1.07)\end{array}$ \\
\hline $\mathbf{1 9 7 7}$ & $\begin{array}{c}16.01 \\
(1.52)\end{array}$ & $\begin{array}{c}12.61 \\
(1.63)\end{array}$ & $\begin{array}{c}\mathbf{1 3 . 2 7} \\
(\mathbf{1 . 7 0})\end{array}$ & $\begin{array}{c}12.64 \\
(1.61)\end{array}$ & $\begin{array}{c}12.14 \\
(1.54)\end{array}$ & $\begin{array}{c}12.48 \\
(1.59)\end{array}$ & $\begin{array}{c}-1.93 \\
(-0.17)\end{array}$ & $\begin{array}{c}-3.43 \\
(-0.43)\end{array}$ & $\begin{array}{c}1.37 \\
(0.21)\end{array}$ & $\begin{array}{c}-1.47 \\
(-0.24)\end{array}$ & $\begin{array}{c}-2.96 \\
(-0.52)\end{array}$ & $\begin{array}{c}-1.88 \\
(-0.35)\end{array}$ \\
\hline $\mathbf{1 9 8 3}$ & $\begin{array}{c}-4.43 \\
(-0.43)\end{array}$ & $\begin{array}{c}-5.38 \\
(-0.74)\end{array}$ & $\begin{array}{c}-5.38 \\
(-0.90)\end{array}$ & $\begin{array}{c}-4.61 \\
(-0.88)\end{array}$ & $\begin{array}{c}-3.96 \\
(-0.85)\end{array}$ & $\begin{array}{c}-3.75 \\
(-0.87)\end{array}$ & $\begin{array}{c}1.76 \\
(0.17)\end{array}$ & $\begin{array}{c}2.14 \\
(0.29)\end{array}$ & $\begin{array}{c}-0.28 \\
(-0.04)\end{array}$ & $\begin{array}{c}-1.26 \\
(-0.24)\end{array}$ & $\begin{array}{c}-1.02 \\
(-0.22)\end{array}$ & $\begin{array}{c}-1.28 \\
(-0.30)\end{array}$ \\
\hline $\mathbf{1 9 8 7}$ & $\begin{array}{c}-6.12 \\
(-0.60)\end{array}$ & $\begin{array}{c}-5.25 \\
(-0.72)\end{array}$ & $\begin{array}{c}-4.44 \\
(-0.74)\end{array}$ & $\begin{array}{c}-3.54 \\
(-0.67)\end{array}$ & $\begin{array}{c}-1.79 \\
(-0.38)\end{array}$ & $\begin{array}{c}-0.94 \\
(-0.22)\end{array}$ & $\begin{array}{c}-7.26 \\
(-0.71)\end{array}$ & $\begin{array}{c}-5.88 \\
(-0.81)\end{array}$ & $\begin{array}{c}-3.42 \\
(-0.57)\end{array}$ & $\begin{array}{c}-4.04 \\
(-0.77)\end{array}$ & $\begin{array}{c}-4.40 \\
(-0.94)\end{array}$ & $\begin{array}{c}-6.08 \\
(-1.42)\end{array}$ \\
\hline $\mathbf{1 9 9 1}$ & $\begin{array}{c}4.68 \\
(0.44)\end{array}$ & $\begin{array}{c}(-1.43 \\
(-0.18)\end{array}$ & $\begin{array}{c}-2.87 \\
(-0.43)\end{array}$ & $\begin{array}{c}-4.61 \\
(-0.78)\end{array}$ & $\begin{array}{c}-5.86 \\
(-1.09)\end{array}$ & $\begin{array}{c}-3.59 \\
(-0.72)\end{array}$ & $\begin{array}{c}4.45 \\
(0.43)\end{array}$ & $\begin{array}{c}5.88 \\
(0.78)\end{array}$ & $\begin{array}{c}3.27 \\
(0.51)\end{array}$ & $\begin{array}{c}1.74 \\
(0.31)\end{array}$ & $\begin{array}{c}0.37 \\
(0.07)\end{array}$ & $\begin{array}{c}-1.33 \\
(-0.28)\end{array}$ \\
\hline $\mathbf{1 9 9 5}$ & $\begin{array}{c}-3.08 \\
(-0.29)\end{array}$ & $\begin{array}{c}5.56 \\
(0.76)\end{array}$ & $\begin{array}{c}1.72 \\
(0.28\end{array}$ & $\begin{array}{c}1.97 \\
(0.38)\end{array}$ & $\begin{array}{c}3.79 \\
(0.81)\end{array}$ & $\begin{array}{c}3.77 \\
(0.80)\end{array}$ & $\begin{array}{c}-1 \\
(-0.09)\end{array}$ & $\begin{array}{c}3.41 \\
(0.47)\end{array}$ & $\begin{array}{c}2.78 \\
(0.47)\end{array}$ & $\begin{array}{c}1.19 \\
(0.23)\end{array}$ & $\begin{array}{c}-0.79 \\
(-0.17)\end{array}$ & $\begin{array}{c}-0.99 \\
(-0.23)\end{array}$ \\
\hline $\mathbf{1 9 9 9}$ & $\begin{array}{c}-4.25 \\
(-0.41)\end{array}$ & $\begin{array}{c}1.39 \\
(0.19)\end{array}$ & $\begin{array}{c}-2.16 \\
(-0.36)\end{array}$ & $\begin{array}{c}1.98 \\
(0.37)\end{array}$ & $\begin{array}{c}-0.20 \\
(-0.04\end{array}$ & $\begin{array}{c}3.17 \\
(0.73)\end{array}$ & $\begin{array}{c}-1.51 \\
(-0.14)\end{array}$ & $\begin{array}{c}2.30 \\
(0.31)\end{array}$ & $\begin{array}{c}0.96 \\
(0.16)\end{array}$ & $\begin{array}{c}1.79 \\
(0.34)\end{array}$ & $\begin{array}{c}2.32 \\
(0.49)\end{array}$ & $\begin{array}{c}2.04 \\
(0.47)\end{array}$ \\
\hline
\end{tabular}

Table E2. Growth rate of quarterly real currency issued

\begin{tabular}{|c|c|c|c|c|c|c|c|c|c|c|c|c|}
\hline Grrealciq & Db1 & Db2 & Db3 & Db4 & Db5 & Db6 & Da1 & $\mathrm{Da} 2$ & Da3 & Da4 & Da5 & Da6 \\
\hline $\begin{array}{c}\text { Composite } \\
\text { dummy }\end{array}$ & $\begin{array}{c}2.09 \\
(0.45)\end{array}$ & $\begin{array}{c}-1.01 \\
(-0.30)\end{array}$ & $\begin{array}{c}1.75 \\
(0.59)\end{array}$ & $\begin{array}{c}1.19 \\
(0.43)\end{array}$ & $\begin{array}{c}2.78 \\
(1.04)\end{array}$ & $\begin{array}{c}6.35 \\
(2.34)\end{array}$ & $\begin{array}{c}-0.19 \\
(-0.04)\end{array}$ & $\begin{array}{c}-1.79 \\
(-0.54)\end{array}$ & $\begin{array}{c}-1.17 \\
(-0.41)\end{array}$ & $\begin{array}{c}-1.78 \\
(-0.66)\end{array}$ & $\begin{array}{c}-0.10 \\
(-0.03)\end{array}$ & $\begin{array}{c}5.64 \\
(2.16)\end{array}$ \\
\hline 1983 & $\begin{array}{c}-8.71 \\
(-0.88)\end{array}$ & $\begin{array}{c}-8.05 \\
(-1.16)\end{array}$ & $\begin{array}{c}-6.30 \\
(-1.11)\end{array}$ & $\begin{array}{c}-4.33 \\
(-0.86)\end{array}$ & $\begin{array}{c}-1.73 \\
(-0.38)\end{array}$ & $\begin{array}{c}-0.45 \\
(-0.11)\end{array}$ & $\begin{array}{c}2.83 \\
(0.29)\end{array}$ & $\begin{array}{c}2.02 \\
(0.29)\end{array}$ & $\begin{array}{l}-0.28 \\
(0.05)\end{array}$ & $\begin{array}{c}-3.36 \\
(-0.67)\end{array}$ & $\begin{array}{c}-2.49 \\
(-0.55)\end{array}$ & $\begin{array}{c}-0.65 \\
(-0.16)\end{array}$ \\
\hline 1987 & $\begin{array}{c}4.31 \\
(0.45)\end{array}$ & $\begin{array}{c}1.12 \\
(0.16)\end{array}$ & $\begin{array}{c}3.95 \\
(0.69)\end{array}$ & $\begin{array}{c}2.47 \\
(0.49)\end{array}$ & $\begin{array}{c}4.18 \\
(0.93)\end{array}$ & $\begin{array}{c}4.81 \\
(1.18)\end{array}$ & $\begin{array}{c}-9.91 \\
(-1.03)\end{array}$ & $\begin{array}{c}-7.57 \\
(-1.10)\end{array}$ & $\begin{array}{c}-4.86 \\
(-0.85)\end{array}$ & $\begin{array}{c}-5.87 \\
(-1.18)\end{array}$ & $\begin{array}{c}-5 \\
(-1.11)\end{array}$ & $\begin{array}{c}-4.84 \\
(-1.18)\end{array}$ \\
\hline 1991 & $\begin{array}{c}-2.15 \\
(-0.22)\end{array}$ & $\begin{array}{c}-9.32 \\
(-1.32)\end{array}$ & $\begin{array}{l}2.16 \\
(0.36\end{array}$ & $\begin{array}{c}1.44 \\
(0.27)\end{array}$ & $\begin{array}{c}2.76 \\
(0.58)\end{array}$ & $\begin{array}{c}3.68 \\
(0.87)\end{array}$ & $\begin{array}{c}-1.55 \\
(-0.15)\end{array}$ & $\begin{array}{c}2.11 \\
(0.29)\end{array}$ & $\begin{array}{c}-0.45 \\
(-0.07)\end{array}$ & $\begin{array}{c}2.96 \\
(0.57)\end{array}$ & $\begin{array}{c}2.54 \\
(0.55)\end{array}$ & $\begin{array}{c}8.87 \\
(2.20)\end{array}$ \\
\hline 1995 & $\begin{array}{c}3.22 \\
(0.31)\end{array}$ & $\begin{array}{c}0.68 \\
(0.09)\end{array}$ & $\begin{array}{c}2.08 \\
(0.33)\end{array}$ & $\begin{array}{c}-1.42 \\
(-0.26)\end{array}$ & $\begin{array}{c}-0.84 \\
(-0.17)\end{array}$ & $\begin{array}{c}-3.61 \\
(-0.83)\end{array}$ & $\begin{array}{c}7.66 \\
(0.77)\end{array}$ & $\begin{array}{c}-6.21 \\
(-0.87)\end{array}$ & $\begin{array}{c}-4.06 \\
(-0.68)\end{array}$ & $\begin{array}{c}-5.22 \\
(-1)\end{array}$ & $\begin{array}{c}-3.62 \\
(-0.78)\end{array}$ & $\begin{array}{c}-0.95 \\
(-0.22)\end{array}$ \\
\hline 1999 & $\begin{array}{l}12.71 \\
(1.31)\end{array}$ & $\begin{array}{l}11.68 \\
(1.73)\end{array}$ & $\begin{array}{c}6.94 \\
(1.23)\end{array}$ & $\begin{array}{c}8.62 \\
(1.78)\end{array}$ & $\begin{array}{c}5.59 \\
(1.28)\end{array}$ & $\begin{array}{c}5.52 \\
(1.38)\end{array}$ & $\begin{array}{c}-0.31 \\
(-0.03)\end{array}$ & $\begin{array}{c}1.74 \\
(0.26)\end{array}$ & $\begin{array}{c}2.63 \\
(0.46)\end{array}$ & $\begin{array}{c}2.93 \\
(0.59)\end{array}$ & $\begin{array}{c}4.11 \\
(0.93)\end{array}$ & $\begin{array}{c}5.75 \\
(1.42)\end{array}$ \\
\hline
\end{tabular}


Table E3. Growth rate of quarterly real broad money supply

\begin{tabular}{|c|c|c|c|c|c|c|c|c|c|c|c|c|}
\hline Grrealm1q & Db1 & Db2 & Db3 & Db4 & Db5 & Db6 & Da1 & $\mathrm{Da} 2$ & Da3 & Da4 & Da5 & Da6 \\
\hline $\begin{array}{c}\text { Composite } \\
\text { dummy }\end{array}$ & $\begin{array}{c}1.18 \\
(0.28)\end{array}$ & $\begin{array}{c}-0.01 \\
-0.004)\end{array}$ & \begin{tabular}{|c}
0.76 \\
$(0.27)$
\end{tabular} & $\begin{array}{l}1.87 \\
(0.73)\end{array}$ & \begin{tabular}{|c|}
4.36 \\
$(1.73)$
\end{tabular} & $\begin{array}{c}5.88 \\
(2.28)\end{array}$ & $\begin{array}{l}-2.19 \\
(-0.52)\end{array}$ & $\begin{array}{c}-3.73 \\
(-1.21)\end{array}$ & \begin{tabular}{|l|}
-1.95 \\
$(0.72)$
\end{tabular} & $\begin{array}{c}0.28 \\
(0.11)\end{array}$ & $\begin{array}{c}4.74 \\
(1.91)\end{array}$ & $\begin{array}{c}6.19 \\
(2.45)\end{array}$ \\
\hline 1983 & $\begin{array}{c}-9.05 \\
(-0.99)\end{array}$ & $\begin{array}{c}-6.65 \\
(-1.02)\end{array}$ & $\begin{array}{l}-1.46 \\
(-0.27)\end{array}$ & $\begin{array}{c}1.46 \\
(0.31)\end{array}$ & \begin{tabular}{|c|}
2.21 \\
$(0.52)$
\end{tabular} & $\begin{array}{c}0.27 \\
(0.07)\end{array}$ & $\begin{array}{l}-10.13 \\
(-1.11)\end{array}$ & $\begin{array}{c}-7.38 \\
(-1.13)\end{array}$ & \begin{tabular}{|l}
-8.07 \\
$(-1.49)$
\end{tabular} & $\begin{array}{c}-6.99 \\
(-1.47)\end{array}$ & $\begin{array}{l}-5.28 \\
(-1.22)\end{array}$ & $\begin{array}{c}-3.96 \\
(-0.99)\end{array}$ \\
\hline 1987 & $\begin{array}{c}5.36 \\
(0.59)\end{array}$ & $\begin{array}{c}2.31 \\
(0.35)\end{array}$ & $\begin{array}{c}1.56 \\
(0.28)\end{array}$ & $\begin{array}{c}3.73 \\
(0.77)\end{array}$ & \begin{tabular}{|c|}
4.45 \\
$(1.02)$
\end{tabular} & $\begin{array}{c}4.78 \\
(1.20)\end{array}$ & $\begin{array}{l}-13.62 \\
(-1.49)\end{array}$ & $\begin{array}{c}-7.62 \\
(-1.14)\end{array}$ & \begin{tabular}{|l}
-4.61 \\
$(-0.83)$
\end{tabular} & $\begin{array}{l}-6.22 \\
(-1.27)\end{array}$ & $\begin{array}{c}-3.61 \\
(-0.80)\end{array}$ & $\begin{array}{c}-2.46 \\
(-0.60)\end{array}$ \\
\hline 1991 & $\begin{array}{c}1 \\
(0.11)\end{array}$ & $\begin{array}{c}-0.31 \\
(-0.04)\end{array}$ & \begin{tabular}{|c|}
-0.55 \\
$(-0.09)$
\end{tabular} & $\begin{array}{c}-2.39 \\
(-0.49)\end{array}$ & $\begin{array}{l}-4.41 \\
(-1.03)\end{array}$ & $\begin{array}{c}-0.97 \\
(-0.24)\end{array}$ & $\begin{array}{l}-3.05 \\
(-0.33)\end{array}$ & $\begin{array}{c}-2.05 \\
(-0.31)\end{array}$ & \begin{tabular}{|c}
1.04 \\
$(0.19)$
\end{tabular} & $\begin{array}{c}1.59 \\
(0.33)\end{array}$ & $\begin{array}{c}4.15 \\
(0.98)\end{array}$ & $\begin{array}{c}2.96 \\
(0.76)\end{array}$ \\
\hline 1995 & $\begin{array}{c}-9.08 \\
(-0.98)\end{array}$ & $\begin{array}{l}3.32 \\
(0.48\end{array}$ & \begin{tabular}{|l}
2.67 \\
$(0.47)$
\end{tabular} & $\begin{array}{c}-1.46 \\
(-0.30)\end{array}$ & \begin{tabular}{|c}
0.14 \\
$(0.03)$
\end{tabular} & $\begin{array}{l}-1.64 \\
(-0.41)\end{array}$ & \begin{tabular}{|l}
9.83 \\
$(1.06)$
\end{tabular} & $\begin{array}{c}-0.88 \\
(-0.13)\end{array}$ & $\begin{array}{l}-2.17 \\
(-0.39)\end{array}$ & $\begin{array}{c}5.33 \\
(1.08)\end{array}$ & $\begin{array}{c}8.61 \\
(1.98)\end{array}$ & $\begin{array}{c}5.69 \\
(1.43)\end{array}$ \\
\hline 1999 & $\begin{array}{c}18.59 \\
(2)\end{array}$ & $\begin{array}{c}3.68 \\
(0.53)\end{array}$ & \begin{tabular}{|l}
2.71 \\
$(0.48)$
\end{tabular} & $\begin{array}{c}5.93 \\
(1.22)\end{array}$ & \begin{tabular}{|l}
5.68 \\
$(1.29)$
\end{tabular} & $\begin{array}{c}5.70 \\
(1.43)\end{array}$ & $\begin{array}{c}6.2 \\
(0.69)\end{array}$ & $\begin{array}{c}0.67 \\
(0.10)\end{array}$ & \begin{tabular}{|l}
4.23 \\
$(0.79)$
\end{tabular} & $\begin{array}{c}4.86 \\
(1.06)\end{array}$ & $\begin{array}{c}6.15 \\
(1.49)\end{array}$ & \begin{tabular}{|c|}
7.29 \\
$(1.93)$
\end{tabular} \\
\hline
\end{tabular}

Table E4. Growth rate of quarterly real monetary base

\begin{tabular}{|c|c|c|c|c|c|c|c|c|c|c|c|c|}
\hline Grrealmbq & Db1 & $\mathrm{Db} 2$ & Db3 & Db4 & Db5 & Db6 & Da1 & Da2 & Da3 & Da4 & Da5 & Da6 \\
\hline $\begin{array}{c}\text { Composite } \\
\text { dummy }\end{array}$ & $\begin{array}{c}5.94 \\
(0.69)\end{array}$ & $\begin{array}{c}4.77 \\
(0.76)\end{array}$ & $\begin{array}{c}0.58 \\
(0.11)\end{array}$ & $\begin{array}{c}0.15 \\
(0.03)\end{array}$ & $\begin{array}{c}-0.07 \\
(-0.01)\end{array}$ & $\begin{array}{c}-3.03 \\
(-0.57)\end{array}$ & $\begin{array}{c}-4.65 \\
(-0.53)\end{array}$ & $\begin{array}{c}3.71 \\
(0.58)\end{array}$ & $\begin{array}{c}-2.15 \\
(-0.38)\end{array}$ & $\begin{array}{l}-1.96 \\
(-0.36)\end{array}$ & $\begin{array}{c}0.07 \\
(0.01)\end{array}$ & $\begin{array}{c}-1.02 \\
(-0.18)\end{array}$ \\
\hline 1983 & $\begin{array}{l}-14.95 \\
(-0.80)\end{array}$ & $\begin{array}{c}-6.75 \\
(-0.49)\end{array}$ & $\begin{array}{c}-1.03 \\
(-0.08)\end{array}$ & $\begin{array}{c}3.74 \\
(0.35)\end{array}$ & $\begin{array}{c}2.54 \\
(0.26)\end{array}$ & $\begin{array}{c}6.97 \\
(0.78)\end{array}$ & $\begin{array}{l}-12.19 \\
(-0.65)\end{array}$ & $\begin{array}{c}2.69 \\
(0.20)\end{array}$ & $\begin{array}{l}1.86 \\
(0.16)\end{array}$ & $\begin{array}{c}4.49 \\
(0.45)\end{array}$ & $\begin{array}{l}10.25 \\
(1.12)\end{array}$ & $\begin{array}{l}11.35 \\
(1.33)\end{array}$ \\
\hline 1987 & $\begin{array}{c}9.77 \\
(0.54)\end{array}$ & $\begin{array}{c}6.74 \\
(0.52)\end{array}$ & $\begin{array}{c}6.19 \\
(0.57)\end{array}$ & $\begin{array}{c}1.55 \\
(0.16)\end{array}$ & $\begin{array}{c}3.92 \\
(0.45)\end{array}$ & $\begin{array}{c}3.32 \\
(0.41)\end{array}$ & $\begin{array}{c}-1.01 \\
(-0.05)\end{array}$ & $\begin{array}{l}-0.93 \\
(-0.07)\end{array}$ & $\begin{array}{c}-9.58 \\
(-0.88)\end{array}$ & $\begin{array}{l}-9.60 \\
(-1)\end{array}$ & $\begin{array}{l}-11.04 \\
(-1.29)\end{array}$ & $\begin{array}{l}-12.02 \\
(-1.51)\end{array}$ \\
\hline 1991 & $\begin{array}{l}30.18 \\
(1.67)\end{array}$ & $\begin{array}{l}7.41 \\
(0.56)\end{array}$ & $\begin{array}{c}8.66 \\
(0.78)\end{array}$ & $\begin{array}{c}-0.78 \\
(-0.08)\end{array}$ & $\begin{array}{c}-2 \\
(-0.23)\end{array}$ & $\begin{array}{c}-3.93 \\
(-0.49)\end{array}$ & $\begin{array}{l}14.50 \\
(0.81)\end{array}$ & $\begin{array}{l}11.97 \\
(0.91)\end{array}$ & $\begin{array}{l}9.08 \\
(0.86)\end{array}$ & $\begin{array}{l}10.94 \\
(1.17)\end{array}$ & $\begin{array}{c}9.45 \\
(1.10)\end{array}$ & $\begin{array}{c}8.70 \\
(1.10)\end{array}$ \\
\hline 1995 & $\begin{array}{c}-4.93 \\
(-0.26)\end{array}$ & $\begin{array}{l}20.42 \\
(1.56)\end{array}$ & $\begin{array}{l}16.05 \\
(1.51\end{array}$ & $\begin{array}{c}8.54 \\
(0.91)\end{array}$ & $\begin{array}{c}1.52 \\
(0.17)\end{array}$ & $\begin{array}{l}-1.23 \\
(-0.15)\end{array}$ & $\begin{array}{l}-36.87 \\
(-1.94)\end{array}$ & $\begin{array}{l}-21.52 \\
(-1.57)\end{array}$ & $\begin{array}{l}-27.29 \\
(-2.44)\end{array}$ & $\begin{array}{l}-28.55 \\
(-2.84)\end{array}$ & $\begin{array}{l}-17.42 \\
(-1.91)\end{array}$ & $\begin{array}{l}-10.94 \\
(-1.33)\end{array}$ \\
\hline 1999 & $\begin{array}{l}1.99 \\
(0.06)\end{array}$ & $\begin{array}{l}-22.18 \\
(-1.28)\end{array}$ & $\begin{array}{l}-31.46 \\
(-2.85)\end{array}$ & $\begin{array}{c}-8.42 \\
(-0.84)\end{array}$ & $\begin{array}{l}-5.87 \\
(-0.67\end{array}$ & $\begin{array}{l}-13.44 \\
(-1.72)\end{array}$ & $\begin{array}{l}24.80 \\
(0.74)\end{array}$ & \begin{tabular}{|l}
45.38 \\
$(2.39)$
\end{tabular} & $\begin{array}{l}44.18 \\
(2.52)\end{array}$ & $\begin{array}{l}39.36 \\
(2.13)\end{array}$ & $\begin{array}{l}38.97 \\
(2.11)\end{array}$ & $\begin{array}{c}36.47 \\
(2)\end{array}$ \\
\hline
\end{tabular}


Table E6. Growth rate of quarterly real public sector credits

\begin{tabular}{|c|c|c|c|c|c|c|c|c|c|c|c|c|}
\hline Grrealpscq & Db1 & Db2 & Db3 & Db4 & Db5 & Db6 & Da1 & $\mathrm{Da} 2$ & Da3 & Da4 & Da5 & Da6 \\
\hline $\begin{array}{c}\text { Composite } \\
\text { dummy }\end{array}$ & $\begin{array}{l}23.72 \\
(1.72)\end{array}$ & $\begin{array}{c}-0.04 \\
(-0.004)\end{array}$ & $\begin{array}{c}1.88 \\
(0.22)\end{array}$ & $\begin{array}{c}-1.07 \\
(-0.14)\end{array}$ & $\begin{array}{l}-1.58 \\
(-0.21)\end{array}$ & $\begin{array}{c}0.78 \\
(0.10)\end{array}$ & $\begin{array}{l}18.14 \\
(1.30)\end{array}$ & $\begin{array}{l}12.57 \\
(1.17)\end{array}$ & $\begin{array}{c}-3.24 \\
(-0.34)\end{array}$ & $\begin{array}{c}-4.01 \\
(-0.47)\end{array}$ & $\begin{array}{c}-2.96 \\
(-0.37)\end{array}$ & $\begin{array}{c}4.99 \\
(0.61)\end{array}$ \\
\hline 1983 & $\begin{array}{c}-6.32 \\
(-0.23)\end{array}$ & $\begin{array}{c}-7.75 \\
(-0.39)\end{array}$ & $\begin{array}{c}-6.13 \\
(-0.38)\end{array}$ & $\begin{array}{c}-4.76 \\
(-0.34)\end{array}$ & $\begin{array}{c}-4.55 \\
(-0.36)\end{array}$ & $\begin{array}{c}-4.79 \\
(-0.41)\end{array}$ & $\begin{array}{c}-7.38 \\
(-0.27)\end{array}$ & $\begin{array}{c}-3.64 \\
(-0.18)\end{array}$ & $\begin{array}{c}-4.51 \\
(-0.28)\end{array}$ & $\begin{array}{c}-9.81 \\
(-0.69)\end{array}$ & $\begin{array}{c}-4.16 \\
(-0.32)\end{array}$ & $\begin{array}{c}-4.44 \\
(-0.37)\end{array}$ \\
\hline 1987 & $\begin{array}{l}11.74 \\
(0.43)\end{array}$ & $\begin{array}{c}6.47 \\
(0.33)\end{array}$ & $\begin{array}{c}-1 \\
(-0.06)\end{array}$ & $\begin{array}{c}5.06 \\
(0.36)\end{array}$ & $\begin{array}{c}3.93 \\
(0.31)\end{array}$ & $\begin{array}{c}2.43 \\
(0.21)\end{array}$ & $\begin{array}{c}-2.93 \\
(-0.11)\end{array}$ & $\begin{array}{c}-4.02 \\
(-0.20)\end{array}$ & $\begin{array}{c}-8.39 \\
(-0.52)\end{array}$ & $\begin{array}{c}-6.06 \\
(-0.43)\end{array}$ & $\begin{array}{c}-6 \\
(-0.47)\end{array}$ & $\begin{array}{c}-3.37 \\
(-0.29)\end{array}$ \\
\hline 1991 & $\begin{array}{l}73.52 \\
(2.94)\end{array}$ & $\begin{array}{l}23.01 \\
(1.24)\end{array}$ & $\begin{array}{l}37.23 \\
(2.32)\end{array}$ & $\begin{array}{l}24.15 \\
(1.71)\end{array}$ & $\begin{array}{l}18.01 \\
(1.41)\end{array}$ & \begin{tabular}{|l|}
17.13 \\
$(1.49)$
\end{tabular} & $\begin{array}{l}79.19 \\
(2.89)\end{array}$ & $\begin{array}{l}79.59 \\
(3.59)\end{array}$ & $\begin{array}{l}14.90 \\
(0.61)\end{array}$ & $\begin{array}{c}9.85 \\
(0.44)\end{array}$ & $\begin{array}{c}1.87 \\
(0.09)\end{array}$ & $\begin{array}{l}40.20 \\
(1.81)\end{array}$ \\
\hline 1995 & $\begin{array}{c}9.68 \\
(0.34)\end{array}$ & $\begin{array}{c}-9.03 \\
(-0.45)\end{array}$ & $\begin{array}{c}-5.12 \\
(-0.31)\end{array}$ & $\begin{array}{l}-11.21 \\
(-0.77)\end{array}$ & $\begin{array}{c}-2.53 \\
(-0.19)\end{array}$ & $\begin{array}{c}-2.17 \\
(-0.17)\end{array}$ & $\begin{array}{c}8.73 \\
(0.31)\end{array}$ & $\begin{array}{c}-1.88 \\
(-0.09)\end{array}$ & $\begin{array}{c}-0.90 \\
(-0.05)\end{array}$ & $\begin{array}{c}2.04 \\
(0.14)\end{array}$ & $\begin{array}{c}2.73 \\
(0.21)\end{array}$ & $\begin{array}{c}8.87 \\
(0.74)\end{array}$ \\
\hline
\end{tabular}

Table E7. Growth rate of quarterly real agricultural credits by CBRT

\begin{tabular}{|c|c|c|c|c|c|c|c|c|c|c|c|c|}
\hline Grrealacq & Db1 & Db2 & Db3 & Db4 & Db5 & Db6 & Da1 & $\mathrm{Da} 2$ & Da3 & Da4 & Da5 & Da6 \\
\hline $\begin{array}{c}\text { Composite } \\
\text { dummy }\end{array}$ & $\begin{array}{l}76.42 \\
(2.16)\end{array}$ & $\begin{array}{l}32.80 \\
(1.13)\end{array}$ & $\begin{array}{l}56.29 \\
(2.44)\end{array}$ & $\begin{array}{l}38.58 \\
(1.82)\end{array}$ & $\begin{array}{l}24.06 \\
(1.16)\end{array}$ & $\begin{array}{l}16.09 \\
(0.78)\end{array}$ & $\begin{array}{l}60.66 \\
(1.42)\end{array}$ & $\begin{array}{c}-7.49 \\
(-0.21)\end{array}$ & $\begin{array}{c}0.20 \\
(0.007)\end{array}$ & \begin{tabular}{|l}
-14.35 \\
$(-0.55)$
\end{tabular} & $\begin{array}{l}-15.80 \\
(-0.63)\end{array}$ & \begin{tabular}{|c}
-25.53 \\
$(-1)$
\end{tabular} \\
\hline 1983 & $\begin{array}{c}-8.61 \\
(-0.13)\end{array}$ & $\begin{array}{l}-16.44 \\
(-0.36)\end{array}$ & $\begin{array}{l}-23.78 \\
(-0.63)\end{array}$ & $\begin{array}{l}-28.68 \\
(-0.88)\end{array}$ & $\begin{array}{l}-30.65 \\
(-1.05)\end{array}$ & $\begin{array}{l}-35.70 \\
(-1.34)\end{array}$ & $\begin{array}{l}-14.93 \\
(-0.23)\end{array}$ & $\begin{array}{l}-15.96 \\
(-0.35)\end{array}$ & $\begin{array}{l}-22.59 \\
(-0.59)\end{array}$ & $\begin{array}{l}-40.37 \\
(-1.23)\end{array}$ & $\begin{array}{l}-47.25 \\
(-1.59)\end{array}$ & \begin{tabular}{|l}
-51.05 \\
$(-1.84)$
\end{tabular} \\
\hline 1987 & $\begin{array}{l}95.03 \\
(1.52)\end{array}$ & $\begin{array}{l}49.42 \\
(0.76)\end{array}$ & $\begin{array}{l}196.61 \\
(4.81)\end{array}$ & $\begin{array}{r}130.21 \\
(3.76)\end{array}$ & $\begin{array}{l}84.81 \\
(2.61)\end{array}$ & $\begin{array}{l}72.57 \\
(2.45)\end{array}$ & $\begin{array}{l}135.58 \\
(2.22)\end{array}$ & $\begin{array}{c}4.95 \\
(0.07)\end{array}$ & \begin{tabular}{|l}
84.60 \\
$(1.93)$
\end{tabular} & $\begin{array}{l}40.70 \\
(0.96)\end{array}$ & $\begin{array}{l}29.62 \\
(0.72)\end{array}$ & \begin{tabular}{|c|}
4.58 \\
$(0.10)$
\end{tabular} \\
\hline 1991 & $\begin{array}{l}141.17 \\
(2.38)\end{array}$ & $\begin{array}{l}71.40 \\
(1.63)\end{array}$ & $\begin{array}{l}49.27 \\
(1.35)\end{array}$ & $\begin{array}{l}32.11 \\
(0.99)\end{array}$ & $\begin{array}{l}25.39 \\
(0.86)\end{array}$ & $\begin{array}{l}20.26 \\
(0.74)\end{array}$ & & & & & & \\
\hline
\end{tabular}

Table E8. Growth rate of monthly real public expenditures (Before election dummies)

\begin{tabular}{|c|c|c|c|c|c|c|c|c|c|c|c|c|c|c|c|c|c|c|}
\hline Grrealpe & $\mathrm{Db} 1$ & Db2 & Db3 & $\mathrm{Db} 4$ & Db5 & Db6 & $\mathrm{Db} 7$ & Db8 & $\mathrm{Db} 9$ & Db10 & Db11 & Db12 & Db13 & Db14 & Db15 & Db16 & Db17 & Db18 \\
\hline $\begin{array}{c}\text { Composite } \\
\text { dummy }\end{array}$ & $\begin{array}{l}-1,24 \\
(-0,23)\end{array}$ & $\begin{array}{c}1,09 \\
(0,27)\end{array}$ & $\begin{array}{c}-2,62 \\
(-0,78)\end{array}$ & \begin{tabular}{|c|}
$-2,23$ \\
$(-0,75)$
\end{tabular} & $\begin{array}{l}-0,62 \\
(-0,22)\end{array}$ & $\begin{array}{l}1,07 \\
(0,42)\end{array}$ & \begin{tabular}{|c}
0,84 \\
$(0,35)$
\end{tabular} & $\begin{array}{c}2,46 \\
(1,09)\end{array}$ & $\begin{array}{c}2,40 \\
(1,09)\end{array}$ & $\begin{array}{c}2,35 \\
(1,09)\end{array}$ & $\begin{array}{c}1,81 \\
(0,85)\end{array}$ & $\begin{array}{l}-0,20 \\
(-0,09)\end{array}$ & \begin{tabular}{|c|}
0,10 \\
$(0,05)$
\end{tabular} & $\begin{array}{c}0,13 \\
(0,06)\end{array}$ & \begin{tabular}{|l}
$-0,44$ \\
$(-0,21)$
\end{tabular} & \begin{tabular}{|l}
$-0,72$ \\
$(-0,33)$
\end{tabular} & $\begin{array}{l}-1,23 \\
(-0,55)\end{array}$ & $\begin{array}{c}0,30 \\
(0,13)\end{array}$ \\
\hline 1991 & $\begin{array}{c}-0,75 \\
(-0,08)\end{array}$ & \begin{tabular}{|c|}
$-0,72$ \\
$(-0,11)$
\end{tabular} & $\begin{array}{l}-4,16 \\
(-0,74)\end{array}$ & \begin{tabular}{|c|}
$-3,17$ \\
$(-0,66)$
\end{tabular} & $\begin{array}{l}-2,61 \\
(-0,60)\end{array}$ & $\begin{array}{l}-2,06 \\
(-0,56)\end{array}$ & $\begin{array}{l}-2,26 \\
(-0,57)\end{array}$ & $\begin{array}{l}-1,89 \\
(-0,55)\end{array}$ & $\begin{array}{l}-0,94 \\
(-0,28)\end{array}$ & $\begin{array}{l}-0,68 \\
(-0,22)\end{array}$ & $\begin{array}{c}-0,28 \\
(-0,09)\end{array}$ & $\begin{array}{l}-0,87 \\
(-0,29)\end{array}$ & \begin{tabular}{|c|}
$-0,86$ \\
$(-0,31)$
\end{tabular} & $\begin{array}{l}-0,70 \\
(-0,26)\end{array}$ & $\begin{array}{l}-0,99 \\
(-0,38)\end{array}$ & $\begin{array}{l}-1,11 \\
(-0,45)\end{array}$ & $\begin{array}{c}-1,08 \\
(-0,44)\end{array}$ & $\begin{array}{c}0,07 \\
(-0,27\end{array}$ \\
\hline 1995 & \begin{tabular}{|c|}
$-4,77$ \\
$(-0,50)$
\end{tabular} & $\begin{array}{c}1,72 \\
(0,24)\end{array}$ & $\begin{array}{c}-0,94 \\
(-0,16)\end{array}$ & $\begin{array}{c}0,22 \\
(0,04)\end{array}$ & $\begin{array}{c}3,46 \\
(0,68)\end{array}$ & $\begin{array}{c}2,26 \\
(0,48)\end{array}$ & $\begin{array}{c}1,68 \\
(0,36)\end{array}$ & $\begin{array}{c}7,49 \\
(1,72)\end{array}$ & $\begin{array}{c}5,51 \\
(1,33)\end{array}$ & $\begin{array}{c}4,31 \\
(1,07)\end{array}$ & $\begin{array}{c}1,39 \\
(0,36)\end{array}$ & $\begin{array}{c}0,19 \\
(0,05)\end{array}$ & \begin{tabular}{|c|}
$-0,49$ \\
$(-0,13)$
\end{tabular} & $\begin{array}{l}-1,56 \\
(-0,44)\end{array}$ & $\begin{array}{c}-2,28 \\
(-0,66)\end{array}$ & $\begin{array}{c}-3,12 \\
(-0,91)\end{array}$ & \begin{tabular}{|c|}
$-4,72$ \\
$(-1,42)$
\end{tabular} & $\begin{array}{c}-5,29 \\
(-1,63)\end{array}$ \\
\hline 1999 & $\begin{array}{c}1,32 \\
(0,14)\end{array}$ & $\begin{array}{c}1,52 \\
(0,22)\end{array}$ & $\begin{array}{c}-3,67 \\
(-0,63)\end{array}$ & $\begin{array}{c}-2,21 \\
(-0,43)\end{array}$ & $\mid \begin{array}{c}-1 \\
(-0,21\end{array}$ & $\begin{array}{c}4,24 \\
(0,98)\end{array}$ & $\begin{array}{c}3,78 \\
(0,95)\end{array}$ & $\begin{array}{c}3,77 \\
(0,99)\end{array}$ & $\begin{array}{c}3,25 \\
(0,88)\end{array}$ & $\begin{array}{c}3,35 \\
(0,94)\end{array}$ & $\begin{array}{c}3,39 \\
(0,98)\end{array}$ & $\begin{array}{c}-0,47 \\
(-0,14)\end{array}$ & \begin{tabular}{|c}
0,49 \\
$(0,14)$
\end{tabular} & $\begin{array}{c}0,99 \\
(0,29)\end{array}$ & $\begin{array}{c}1,45 \\
(0,42)\end{array}$ & $\begin{array}{c}1,94 \\
(0,58)\end{array}$ & $\begin{array}{c}2,29 \\
(0,69)\end{array}$ & $\begin{array}{c}1,88 \\
(0,57)\end{array}$ \\
\hline
\end{tabular}


Table E9. Growth rate of monthly real public expenditures (After election dummies)

\begin{tabular}{|c|c|c|c|c|c|c|c|c|c|c|c|c|c|c|c|c|c|c|}
\hline Grrealpe & Dal & $\mathrm{Da} 2$ & Da3 & Da4 & Da5 & Da6 & $\mathrm{Da} 7$ & Da8 & $\mathrm{Da} 9$ & Da10 & Da11 & Da12 & Da13 & Da14 & Da15 & Da16 & Da17 & Da18 \\
\hline $\begin{array}{c}\text { Composite } \\
\text { dummy }\end{array}$ & $\begin{array}{c}-2,09 \\
(-0,38)\end{array}$ & $\begin{array}{c}-1,47 \\
(-0,36)\end{array}$ & $\begin{array}{c}-5,27 \\
(-1,57)\end{array}$ & $\begin{array}{c}0,92 \\
(0,31)\end{array}$ & $\begin{array}{c}0,39 \\
(0,15)\end{array}$ & $\begin{array}{c}0,54 \\
(0,22)\end{array}$ & $\begin{array}{c}0,72 \\
(0,31)\end{array}$ & $\begin{array}{c}1 \\
(0,46)\end{array}$ & $\begin{array}{c}1,67 \\
(0,81)\end{array}$ & $\begin{array}{c}1,93 \\
(0,96)\end{array}$ & $\begin{array}{c}1,51 \\
(0,76)\end{array}$ & $\begin{array}{c}1,64 \\
(0,84)\end{array}$ & $\begin{array}{c}2,06 \\
(1,06)\end{array}$ & $\begin{array}{c}1,92 \\
(0,96)\end{array}$ & $\begin{array}{c}0,85 \\
(0,42)\end{array}$ & $\begin{array}{c}0,39 \\
(0,19)\end{array}$ & $\begin{array}{c}0,03 \\
(0,02)\end{array}$ & $\begin{array}{c}1,96 \\
(0,88)\end{array}$ \\
\hline 1991 & $\begin{array}{c}-1,02 \\
(-0,11)\end{array}$ & $\begin{array}{c}-1,20 \\
(-0,17)\end{array}$ & $\begin{array}{c}-0,79 \\
(-0,14)\end{array}$ & $\begin{array}{c}0,67 \\
(0,14)\end{array}$ & $\begin{array}{c}-0,12 \\
(-0,02)\end{array}$ & $\begin{array}{c}1,91 \\
(0,49)\end{array}$ & $\begin{array}{c}1,87 \\
(0,52)\end{array}$ & $\begin{array}{c}1,54 \\
(0,45)\end{array}$ & $\begin{array}{c}1,03 \\
(0,32)\end{array}$ & $\begin{array}{c}0,96 \\
(0,32)\end{array}$ & $\begin{array}{c}0,77 \\
(0,26)\end{array}$ & $\begin{array}{c}0,52 \\
(0,18)\end{array}$ & $\begin{array}{c}0,42 \\
(0,15)\end{array}$ & $\begin{array}{c}0,36 \\
(0,14)\end{array}$ & $\begin{array}{l}-2,05 \\
(-0,80)\end{array}$ & $\begin{array}{l}-2,31 \\
(-0,93)\end{array}$ & $\begin{array}{c}-2,28 \\
(-0,94)\end{array}$ & $\begin{array}{l}-0,65 \\
(-0,27)\end{array}$ \\
\hline 1995 & $\begin{array}{c}-8,43 \\
(-0,88)\end{array}$ & $\begin{array}{r}-5,83 \\
(0,83)\end{array}$ & $\begin{array}{c}-7,86 \\
(-1,33)\end{array}$ & $\begin{array}{c}8,28 \\
(1,56)\end{array}$ & $\begin{array}{c}7,26 \\
(1,51)\end{array}$ & $\begin{array}{c}6,16 \\
(1,32)\end{array}$ & $\begin{array}{c}5,93 \\
(1,32)\end{array}$ & $\begin{array}{c}6,58 \\
(1,58)\end{array}$ & $\begin{array}{c}5,58 \\
(1,36)\end{array}$ & $\begin{array}{c}5,63 \\
(1,42)\end{array}$ & $\begin{array}{c}4,78 \\
(1,25)\end{array}$ & $\begin{array}{c}4,48 \\
(1,19)\end{array}$ & $\begin{array}{c}5,61 \\
(1,52)\end{array}$ & $\begin{array}{c}5 \\
(1,38)\end{array}$ & $\begin{array}{c}5,85 \\
(1,64)\end{array}$ & $\begin{array}{c}5,06 \\
(1,44)\end{array}$ & $\begin{array}{c}5,15 \\
(1,49)\end{array}$ & $\begin{array}{c}5,97 \\
(1,73)\end{array}$ \\
\hline 1999 & $\begin{array}{c}2,75 \\
(0,29)\end{array}$ & $\begin{array}{c}2,85 \\
(0,41)\end{array}$ & $\begin{array}{c}-7,25 \\
(-1,27)\end{array}$ & $\begin{array}{c}-5,39 \\
(-1,10)\end{array}$ & \begin{tabular}{|c|}
$-4,43$ \\
$(-0,99)$
\end{tabular} & $\begin{array}{l}-4,96 \\
(-1,22)\end{array}$ & $\begin{array}{c}-4,19 \\
(-1,10)\end{array}$ & $\begin{array}{c}-3,62 \\
(-0,99)\end{array}$ & $\begin{array}{c}-0,65 \\
(-0,18)\end{array}$ & \begin{tabular}{|c|}
$-0,04$ \\
$(-0,01)$
\end{tabular} & $\begin{array}{c}-0,47 \\
(-0,15)\end{array}$ & $\begin{array}{c}0,92 \\
(0,29)\end{array}$ & $\begin{array}{c}1,29 \\
(0,43)\end{array}$ & $\begin{array}{c}1,32 \\
(0,45)\end{array}$ & $\begin{array}{c}1,71 \\
(0,60)\end{array}$ & $\begin{array}{c}1,98 \\
(0,71)\end{array}$ & $\begin{array}{c}2,11 \\
(0,77)\end{array}$ & $\begin{array}{c}2,30 \\
(0,86)\end{array}$ \\
\hline
\end{tabular}

Table E10. Growth rate of monthly real public personnel expenditures (Before election dummies)

\begin{tabular}{|c|c|c|c|c|c|c|c|c|c|c|c|c|c|c|c|c|c|c|}
\hline Grrealppe & Db1 & $\mathrm{Db} 2$ & Db3 & Db4 & Db5 & Db6 & $\mathrm{Db} 7$ & $\mathrm{Db8}$ & $\mathrm{Db} 9$ & Db10 & Db11 & Db12 & Db13 & Db14 & Db15 & Db16 & Db17 & Db18 \\
\hline $\begin{array}{c}\text { Composite } \\
\text { dummy }\end{array}$ & $\begin{array}{c}1,99 \\
(0,51)\end{array}$ & $\begin{array}{c}0,49 \\
(0,17)\end{array}$ & $\begin{array}{c}0,22 \\
(0,09)\end{array}$ & $\begin{array}{c}0,56 \\
(0,27)\end{array}$ & $\begin{array}{c}0,51 \\
(0,27)\end{array}$ & $\begin{array}{c}0,74 \\
(0,43)\end{array}$ & $\begin{array}{c}0,47 \\
(0,29)\end{array}$ & $\begin{array}{c}1,25 \\
(0,79)\end{array}$ & $\begin{array}{c}0,12 \\
(0,08)\end{array}$ & $\begin{array}{c}0,21 \\
(0,14)\end{array}$ & $\begin{array}{l}-0,11 \\
(-0,07)\end{array}$ & $\begin{array}{c}0,65 \\
-0,44)\end{array}$ & $\begin{array}{l}-0,97 \\
(-0,65)\end{array}$ & $\begin{array}{l}-1,71 \\
(-1,13)\end{array}$ & \begin{tabular}{|l|}
$-1,98$ \\
$(-1,28)$
\end{tabular} & $\begin{array}{l}-2,38 \\
(-1,52)\end{array}$ & $\begin{array}{c}-2,23 \\
(-1,38)\end{array}$ & $\begin{array}{l}-2,47 \\
(-1,46)\end{array}$ \\
\hline 1987 & $\begin{array}{l}-2,10 \\
(-0,27)\end{array}$ & $\begin{array}{l}-2,61 \\
(-0,48)\end{array}$ & $\begin{array}{l}-1,65 \\
(-0,37)\end{array}$ & $\begin{array}{c}0,33 \\
(0,08)\end{array}$ & $\begin{array}{l}-0,34 \\
(-0,09)\end{array}$ & \begin{tabular}{c|}
$-0,63$ \\
$(-0,19)$
\end{tabular} & $\begin{array}{c}-0,72 \\
(-0,24)\end{array}$ & $\begin{array}{l}-0,81 \\
(-0,29)\end{array}$ & $\begin{array}{c}-0,82 \\
(-0,29)\end{array}$ & $\begin{array}{l}-0,83 \\
(-0,29)\end{array}$ & $\begin{array}{c}-0,84 \\
(-0,30)\end{array}$ & $\begin{array}{c}-0,89 \\
(-0,32)\end{array}$ & $\begin{array}{c}-0,89 \\
(-0,32)\end{array}$ & $\begin{array}{c}-0,88 \\
(-0,32)\end{array}$ & \begin{tabular}{|c|}
$-0,76$ \\
$(-0,27)$
\end{tabular} & $\begin{array}{c}-0,79 \\
(-0,28)\end{array}$ & $\begin{array}{c}-0,79 \\
(-0,28)\end{array}$ & $\begin{array}{l}-0,81 \\
(-0,29)\end{array}$ \\
\hline 1991 & \begin{tabular}{|c}
4,69 \\
$(0,59)$
\end{tabular} & \begin{tabular}{|c|}
2,37 \\
$(0,41)$
\end{tabular} & $\begin{array}{c}1,71 \\
(0,34)\end{array}$ & $\begin{array}{c}2,30 \\
(0,51)\end{array}$ & $\begin{array}{c}4,03 \\
(0,95)\end{array}$ & \begin{tabular}{|c|}
5,76 \\
$(1,43)$
\end{tabular} & $\begin{array}{c}4,48 \\
(1,12)\end{array}$ & \begin{tabular}{|c|}
6,22 \\
$(1,55)$
\end{tabular} & $\begin{array}{c}2,42 \\
(0,62)\end{array}$ & $\begin{array}{c}3,18 \\
(0,85)\end{array}$ & $\begin{array}{c}3,52 \\
(0,98)\end{array}$ & $\begin{array}{c}2,74 \\
(0,79)\end{array}$ & $\begin{array}{c}1,23 \\
(0,37)\end{array}$ & $\begin{array}{c}-0,99 \\
(-0,31)\end{array}$ & $\begin{array}{c}-2,19 \\
(-0,72)\end{array}$ & $\begin{array}{l}-2,46 \\
(-0,83)\end{array}$ & $\begin{array}{c}-1,10 \\
(-0,38)\end{array}$ & $\begin{array}{l}-0,07 \\
(-0,03)\end{array}$ \\
\hline 1995 & $\begin{array}{c}2,86 \\
(0,37)\end{array}$ & $\begin{array}{c}0,05 \\
(0,01)\end{array}$ & $\begin{array}{l}-1,25 \\
(-0,27)\end{array}$ & $\begin{array}{l}-2,25 \\
(-0,27)\end{array}$ & $\begin{array}{c}-3 \\
(-0,79)\end{array}$ & $\begin{array}{c}-3,05 \\
(-0,87)\end{array}$ & $\begin{array}{c}-2,23 \\
(-0,67)\end{array}$ & $\begin{array}{c}0,05 \\
(0,02)\end{array}$ & $\begin{array}{c}-0,46 \\
(-0,15)\end{array}$ & $\begin{array}{c}-0,58 \\
(-0,19)\end{array}$ & $\begin{array}{c}-1,97 \\
(-0,68)\end{array}$ & $\begin{array}{c}-2,64 \\
(-0,94)\end{array}$ & $\begin{array}{l}-2,60 \\
(-0,95)\end{array}$ & $\begin{array}{c}-2,99 \\
(-1,13)\end{array}$ & $\begin{array}{c}-3,32 \\
(-1,28)\end{array}$ & $\begin{array}{c}-3,19 \\
(-1,25)\end{array}$ & $\begin{array}{c}-3,28 \\
(-1,30)\end{array}$ & $\begin{array}{l}-3,35 \\
(-0,05)\end{array}$ \\
\hline 1999 & $\begin{array}{c}2,81 \\
(0,36)\end{array}$ & $\begin{array}{c}2,77 \\
(0,50)\end{array}$ & $\begin{array}{c}1,75 \\
(0,39)\end{array}$ & $\begin{array}{c}2,06 \\
(0,53)\end{array}$ & $\begin{array}{l}2,21 \\
(0,63\end{array}$ & $\begin{array}{c}2,43 \\
(0,76)\end{array}$ & $\begin{array}{c}1,95 \\
(0,66)\end{array}$ & $\begin{array}{c}2,18 \\
(0,78)\end{array}$ & $\begin{array}{c}1,39 \\
(0,53)\end{array}$ & $\begin{array}{c}1,39 \\
(0,55)\end{array}$ & $\begin{array}{c}1,46 \\
(0,61)\end{array}$ & $\begin{array}{c}1,27 \\
(0,55)\end{array}$ & $\begin{array}{c}1,27 \\
(0,57)\end{array}$ & $\begin{array}{c}1,18 \\
(0,55)\end{array}$ & $\begin{array}{c}1,11 \\
(0,53)\end{array}$ & $\begin{array}{c}0,79 \\
(0,39)\end{array}$ & $\begin{array}{c}0,58 \\
(0,29)\end{array}$ & $\begin{array}{c}0,42 \\
(0,22)\end{array}$ \\
\hline
\end{tabular}

Table E11. Growth rate of monthly real public personnel expenditures (After election dummies)

\begin{tabular}{|c|c|c|c|c|c|c|c|c|c|c|c|c|c|c|c|c|c|c|}
\hline Grrealppe & Da1 & $\mathrm{Da} 2$ & Da3 & $\mathrm{Da} 4$ & Da5 & Da6 & Da7 & Da8 & Da9 & Da10 & Da11 & Da12 & Da13 & Da14 & Da15 & Da16 & Da17 & Da18 \\
\hline $\begin{array}{c}\text { Composite } \\
\text { dummy }\end{array}$ & $\begin{array}{c}4,13 \\
(1,06)\end{array}$ & $\begin{array}{c}-0,68 \\
(-0,24)\end{array}$ & $\begin{array}{c}2,54 \\
(1,08)\end{array}$ & $\begin{array}{c}-0,47 \\
(-0,23)\end{array}$ & $\begin{array}{c}-0,95 \\
(-0,50)\end{array}$ & \begin{tabular}{|c|}
$-1,39$ \\
$(-0,79)$
\end{tabular} & $\begin{array}{c}-0,95 \\
(-0,57)\end{array}$ & $\begin{array}{c}-0,83 \\
(-0,52)\end{array}$ & $\begin{array}{c}-1,94 \\
(-1,27)\end{array}$ & \begin{tabular}{|c|}
$-1,85$ \\
$(-1,25)$
\end{tabular} & \begin{tabular}{|c|}
$-2,06$ \\
$(-1,43)$
\end{tabular} & $\begin{array}{c}-2,41 \\
(-1,68)\end{array}$ & $\begin{array}{c}-2,09 \\
(-1,46)\end{array}$ & $\begin{array}{c}-2,35 \\
(-1,63)\end{array}$ & \begin{tabular}{|c|}
$-1,96$ \\
$(-1,32)$ \\
\end{tabular} & \begin{tabular}{|c|}
$-2,19$ \\
$(-1,46)$
\end{tabular} & $\begin{array}{c}-2,02 \\
(-1,30)\end{array}$ & $\begin{array}{c}-2,42 \\
(-1,47)\end{array}$ \\
\hline 1987 & \begin{tabular}{|c|}
$-3,52$ \\
$(-0,45)$
\end{tabular} & $\begin{array}{c}-9,94 \\
(-1,83)\end{array}$ & $\begin{array}{c}7,91 \\
(1,78)\end{array}$ & $\begin{array}{c}0,16 \\
(0,04)\end{array}$ & \begin{tabular}{|c|}
$-1,86$ \\
$(-0,53)$
\end{tabular} & $\begin{array}{c}-2,45 \\
(-0,76)\end{array}$ & $\begin{array}{l}-2,09 \\
(-0,70)\end{array}$ & $\begin{array}{l}-2,25 \\
(-0,81)\end{array}$ & $\begin{array}{l}-2,24 \\
(-0,85)\end{array}$ & $\begin{array}{c}-2,25 \\
(-0,89)\end{array}$ & $\begin{array}{c}-2,21 \\
(-0,92)\end{array}$ & $\begin{array}{c}-2,62 \\
(-1,14)\end{array}$ & $\begin{array}{l}-2,56 \\
(-1,15)\end{array}$ & \begin{tabular}{|c|}
$-2,33$ \\
$(-1,08)$
\end{tabular} & $\begin{array}{c}-0,76 \\
(-0,36)\end{array}$ & $\begin{array}{c}-1,13 \\
(-0,55)\end{array}$ & $\begin{array}{l}-0,98 \\
(-0,49)\end{array}$ & $\begin{array}{c}-1,13 \\
(-0,58)\end{array}$ \\
\hline 1991 & $\begin{array}{c}1,29 \\
(0,16)\end{array}$ & $\begin{array}{c}1,42 \\
(0,26)\end{array}$ & $\begin{array}{c}-1,15 \\
(-0,25)\end{array}$ & $\begin{array}{c}-0,43 \\
(-0,10)\end{array}$ & $\begin{array}{c}1,09 \\
(0,31)\end{array}$ & \begin{tabular}{|c|}
0,85 \\
$(0,26)$
\end{tabular} & $\begin{array}{c}1,10 \\
(0,36)\end{array}$ & $\begin{array}{c}1,41 \\
(0,49)\end{array}$ & $\begin{array}{c}0,89 \\
(0,33)\end{array}$ & $\begin{array}{c}0,58 \\
(0,23)\end{array}$ & $\begin{array}{c}0,15 \\
(0,06)\end{array}$ & $\begin{array}{c}-0,09 \\
(-0,04)\end{array}$ & $\begin{array}{c}-0,23 \\
(-0,10)\end{array}$ & $\begin{array}{c}-0,40 \\
(-0,18)\end{array}$ & $\begin{array}{c}-0,47 \\
(-0,22)\end{array}$ & $\begin{array}{c}-0,57 \\
(-0,27)\end{array}$ & $\begin{array}{c}-0,12 \\
(-0,06)\end{array}$ & $\begin{array}{c}-0,004 \\
(-0,002)\end{array}$ \\
\hline 1995 & \begin{tabular}{|l|}
19,43 \\
$(2,52)$
\end{tabular} & $\begin{array}{c}6,79 \\
(1,20)\end{array}$ & \begin{tabular}{|c|}
3,48 \\
$(0,74)$
\end{tabular} & $\begin{array}{c}-0,51 \\
(-0,12)\end{array}$ & \begin{tabular}{|c|}
$-1,77$ \\
$(-0,47)$
\end{tabular} & $\begin{array}{c}-2,58 \\
(-0,74)\end{array}$ & $\begin{array}{l}-1,45 \\
(-0,45)\end{array}$ & $\begin{array}{c}-0,80 \\
(-0,26)\end{array}$ & $\begin{array}{l}-0,63 \\
(-0,22)\end{array}$ & $\begin{array}{c}-0,73 \\
(-0,26)\end{array}$ & $\begin{array}{c}-1,43 \\
(-0,54)\end{array}$ & $\begin{array}{c}-1,69 \\
(-0,66)\end{array}$ & $\begin{array}{c}-0,31 \\
(-0,12)\end{array}$ & \begin{tabular}{|c|}
$-0,45$ \\
$(-0,19)$
\end{tabular} & $\begin{array}{c}-0,47 \\
(-0,21)\end{array}$ & $\begin{array}{c}0,12 \\
(0,06)\end{array}$ & $\begin{array}{c}0,04 \\
(0,02)\end{array}$ & $\begin{array}{c}-0,11 \\
(-0,05)\end{array}$ \\
\hline 1999 & $\begin{array}{c}-0,45 \\
(-0,06)\end{array}$ & $\begin{array}{c}-0,45 \\
(-0,08)\end{array}$ & $\begin{array}{c}-0,60 \\
(-0,13)\end{array}$ & $\begin{array}{c}-1,52 \\
(-0,29)\end{array}$ & \begin{tabular}{|c|}
$-1,11$ \\
$(-0,32)$
\end{tabular} & \begin{tabular}{|c|}
$-1,13$ \\
$(-0,35)$
\end{tabular} & $\begin{array}{l}-1,09 \\
(-0,37)\end{array}$ & $\begin{array}{c}-1,37 \\
(-0,49)\end{array}$ & $\begin{array}{c}-4,24 \\
(-1,62)\end{array}$ & \begin{tabular}{|c|}
$-3,48$ \\
$(-1,39)$
\end{tabular} & $\begin{array}{c}-2,93 \\
(-1,22)\end{array}$ & \begin{tabular}{|c|}
$-2,50$ \\
$(-1,07)$
\end{tabular} & $\begin{array}{c}-2,21 \\
(-0,98)\end{array}$ & $\begin{array}{c}-1,99 \\
(-0,92)\end{array}$ & \begin{tabular}{|c|}
$-1,78$ \\
$(-0,84)$
\end{tabular} & \begin{tabular}{|c|}
$-1,73$ \\
$(-0,84)$
\end{tabular} & $\begin{array}{l}-1,53 \\
(-0,76)\end{array}$ & $\begin{array}{c}-1,15 \\
(-0,74)\end{array}$ \\
\hline
\end{tabular}


Table E12. Growth rate of monthly real tax revenues

(Before election dummies)

\begin{tabular}{|c|c|c|c|c|c|c|c|c|c|c|c|c|c|c|c|c|c|c|}
\hline Grrealtr & $\mathrm{Db} 1$ & $\mathrm{Db} 2$ & $\mathrm{Db3}$ & $\mathrm{Db} 4$ & Db5 & Db6 & $\mathrm{Db} 7$ & Db8 & Db9 & Db10 & Db11 & Db12 & Db13 & Db14 & Db15 & Db16 & Db17 & Db18 \\
\hline & $\begin{array}{c}-1,79 \\
(-0,56)\end{array}$ & $\begin{array}{l}-0,93 \\
(-0,40)\end{array}$ & $\begin{array}{c}-3,97 \\
(-2,15)\end{array}$ & $\mid \begin{array}{l}-3,54 \\
(-2,18)\end{array}$ & $\begin{array}{c}-2,93 \\
(-1,99)\end{array}$ & $\begin{array}{c}-3,18 \\
(-2,35)\end{array}$ & $\begin{array}{l}-2,51 \\
(-1,97)\end{array}$ & $\begin{array}{c}-2,15 \\
(-1,77)\end{array}$ & $\begin{array}{c}-1,94 \\
(-1,66)\end{array}$ & $\begin{array}{c}-1,59 \\
(-1,41)\end{array}$ & $\begin{array}{l}-1,57 \\
(-1,42)\end{array}$ & $\begin{array}{c}-1,81 \\
(-1,66)\end{array}$ & $\begin{array}{l}-2,08 \\
(-1,90)\end{array}$ & $\begin{array}{c}-1,20 \\
(-1,08)\end{array}$ & $\begin{array}{c}-1,49 \\
(-1,32)\end{array}$ & $\begin{array}{l}-1,06 \\
(-0,92)\end{array}$ & $\begin{array}{c}-1,01 \\
(-0,87)\end{array}$ & $\begin{array}{c}-0,77 \\
(-0,64)\end{array}$ \\
\hline & $\begin{array}{c}-0,25 \\
(-0,05)\end{array}$ & $\begin{array}{c}-1,59 \\
(-0,42)\end{array}$ & $\begin{array}{c}0,02 \\
(0,008)\end{array}$ & $(-0,34)$ & $(-0,43)$ & $\begin{array}{c}-0,98 \\
(-0,44)\end{array}$ & $\begin{array}{l}-1,32 \\
(-0,63)\end{array}$ & $\begin{array}{c}-0,99 \\
(-0,50)\end{array}$ & $\begin{array}{l}-1,09 \\
(-0,58)\end{array}$ & & $\begin{array}{l}-1,16 \\
(-0,67)\end{array}$ & $\begin{array}{c}-1,30 \\
(-0,77)\end{array}$ & $\begin{array}{l}-1,61 \\
(-0,98)\end{array}$ & $\begin{array}{c}-2,08 \\
(-1,29)\end{array}$ & $\begin{array}{c}-1,89 \\
(-1,18)\end{array}$ & $\begin{array}{c}-1,58 \\
(-1)\end{array}$ & $\begin{array}{l}-1,19 \\
(-0,77)\end{array}$ & 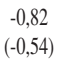 \\
\hline 15 & $\begin{array}{c}-3,03 \\
(-0,55)\end{array}$ & \begin{tabular}{|c}
$-0,76$ \\
$(-0,19)$
\end{tabular} & $\begin{array}{l}-1,42 \\
(-0,43)\end{array}$ & \begin{tabular}{|c}
$-1,94$ \\
$(-0,67)$
\end{tabular} & $\begin{array}{c}-1,98 \\
(-0,75)\end{array}$ & \begin{tabular}{|c}
$-3,55$ \\
$(-1,46)$
\end{tabular} & $\begin{array}{l}-2,20 \\
(-0,94)\end{array}$ & $\begin{array}{l}-1,73 \\
(-0,77)\end{array}$ & $\begin{array}{l}-2,44 \\
(-1,14)\end{array}$ & $\begin{array}{c}-2,49 \\
(-1,21)\end{array}$ & $\begin{array}{l}-2,84 \\
(-1,42)\end{array}$ & $\begin{array}{c}-3,54 \\
(-1,83)\end{array}$ & $\begin{array}{l}-3,84 \\
(-2,03)\end{array}$ & $\begin{array}{c}-3,99 \\
(-2,14)\end{array}$ & $\begin{array}{c}-4,14 \\
(-2,31)\end{array}$ & $\begin{array}{l}-4,04 \\
(-2,29)\end{array}$ & $\begin{array}{l}-4,34 \\
(-2,49)\end{array}$ & $\begin{array}{l}-4,45 \\
(-2,57)\end{array}$ \\
\hline & $\begin{array}{c}-2,03 \\
(-0,37)\end{array}$ & \begin{tabular}{|c}
$-0,16$ \\
$(-0,04)$
\end{tabular} & $\begin{array}{l}-10,50 \\
(-3,33)\end{array}$ & \begin{tabular}{|c}
$-7,54$ \\
$(-2,74)$
\end{tabular} & \begin{tabular}{|c|}
$-5,46$ \\
$(-2,18)$
\end{tabular} & $\begin{array}{l}-4,63 \\
(-1,99)\end{array}$ & $\begin{array}{c}-3,86 \\
(-1,77)\end{array}$ & \begin{tabular}{|c}
$-3,44$ \\
$(-1,66)$
\end{tabular} & $\begin{array}{c}-2,20 \\
(-1,13)\end{array}$ & \begin{tabular}{|c}
$-1,59$ \\
$(-0,88)$
\end{tabular} & $\begin{array}{c}-1,05 \\
(-0,59)\end{array}$ & \begin{tabular}{|c}
$-0,54$ \\
$(-0,32)$
\end{tabular} & $\begin{array}{c}-0,11 \\
(-0,06)\end{array}$ & $\begin{array}{c}2,24 \\
(1,39)\end{array}$ & $\begin{array}{c}1,61 \\
(1,03)\end{array}$ & $\begin{array}{c}1,68 \\
(1,10)\end{array}$ & $\begin{array}{c}1,57 \\
(1,06)\end{array}$ & $\begin{array}{c}1,45 \\
(0,99)\end{array}$ \\
\hline
\end{tabular}

Table E13. Growth rate of monthly real tax revenues (After election dummies)

\begin{tabular}{|c|c|c|c|c|c|c|c|c|c|c|c|c|c|c|c|c|c|c|}
\hline Grrealtr & Da1 & Da2 & Da3 & Da4 & Da5 & Da6 & Da7 & Da8 & Da9 & Da10 & Da11 & Da12 & Da13 & Da14 & Da15 & Da16 & Da17 & Da18 \\
\hline $\begin{array}{c}\text { Composite } \\
\text { dummy }\end{array}$ & $\begin{array}{c}-0,68 \\
(-0,23)\end{array}$ & \begin{tabular}{|c|}
$-1,77$ \\
$(-0,79)$
\end{tabular} & $\begin{array}{l}-1,71 \\
(-0,98)\end{array}$ & \begin{tabular}{|c|}
$-0,45$ \\
$(-0,30)$
\end{tabular} & $\begin{array}{c}0,04 \\
(0,03)\end{array}$ & \begin{tabular}{|c|}
$-0,85$ \\
$(-0,67)$
\end{tabular} & $\begin{array}{c}-0,45 \\
(-0,37)\end{array}$ & \begin{tabular}{|c|}
$-0,67$ \\
$(-0,58)$
\end{tabular} & \begin{tabular}{|c|}
$-0,26$ \\
$(-0,24)$
\end{tabular} & \begin{tabular}{|c|}
0,64 \\
$(0,59)$
\end{tabular} & $\begin{array}{c}0,47 \\
(0,44)\end{array}$ & \begin{tabular}{|c|}
0,05 \\
$(0,04)$
\end{tabular} & $\begin{array}{c}-0,47 \\
(-0,45)\end{array}$ & $\begin{array}{c}0,21 \\
(0,19)\end{array}$ & $\begin{array}{c}0,03 \\
(0,02)\end{array}$ & ,, 58 & $\begin{array}{c}0,59 \\
(0,52)\end{array}$ & $\begin{array}{l}0,89 \\
(0,75)\end{array}$ \\
\hline & $\begin{array}{c}-0,48 \\
(-0,09)\end{array}$ & \begin{tabular}{|c|}
$-1,72$ \\
$(-0,45)$
\end{tabular} & $\begin{array}{l}-1,41 \\
(-0,45)\end{array}$ & \begin{tabular}{|l|}
$-1,67$ \\
$(-0,61)$
\end{tabular} & $\begin{array}{l}-1,78 \\
(-0,73)\end{array}$ & \begin{tabular}{|c|}
$-1,14$ \\
$(-0,51)$
\end{tabular} & \begin{tabular}{|c|}
$-1,36$ \\
$(-0,65)$
\end{tabular} & \begin{tabular}{|c|}
$-0,90$ \\
$(-0,46)$
\end{tabular} & \begin{tabular}{|c|}
$-0,92$ \\
$(-0,49)$
\end{tabular} & \begin{tabular}{|c|}
$-0,56$ \\
$(-0,31)$
\end{tabular} & $\begin{array}{c}-0,43 \\
(-0,25)\end{array}$ & \begin{tabular}{|c|}
$-0,64$ \\
$(-0,39)$
\end{tabular} & $\begin{array}{c}-0,55 \\
(-0,34)\end{array}$ & $\begin{array}{c}-0,36 \\
(-0,23)\end{array}$ & $\begin{array}{c}-0,24 \\
(-0,16)\end{array}$ & \begin{tabular}{|c|}
0,23 \\
$(0,16)$
\end{tabular} & \begin{tabular}{|c|}
0.08 \\
$(0,06)$
\end{tabular} & $\begin{array}{c}0,44 \\
(0,32)\end{array}$ \\
\hline & $\begin{array}{c}-1,83 \\
(-0,34)\end{array}$ & $\begin{array}{c}-3,11 \\
(-0,80)\end{array}$ & $\begin{array}{l}-1,41 \\
(-0,42)\end{array}$ & $\begin{array}{c}0,38 \\
(0,13)\end{array}$ & $\begin{array}{c}2,43 \\
(0,91)\end{array}$ & $\begin{array}{c}0,85 \\
(0,36)\end{array}$ & $\begin{array}{c}1,08 \\
(0,48)\end{array}$ & $\begin{array}{c}0,69 \\
(0,33)\end{array}$ & $\begin{array}{c}0,41 \\
(0,20)\end{array}$ & $\begin{array}{c}0,13 \\
(0,06)\end{array}$ & $\begin{array}{c}-0,14 \\
(-0,07)\end{array}$ & $\begin{array}{c}-0,29 \\
(-0,17)\end{array}$ & $\begin{array}{c}-0,54 \\
(-0,31)\end{array}$ & $\begin{array}{c}-0,37 \\
(-0,22)\end{array}$ & $\begin{array}{c}-1,37 \\
(-0,85)\end{array}$ & $\begin{array}{c}-0,63 \\
(-0,41)\end{array}$ & $\begin{array}{c}-0,97 \\
(-0,66)\end{array}$ & $\begin{array}{l}-0,7 \\
(-0,5\end{array}$ \\
\hline & $\begin{array}{c}0,25 \\
(0,05)\end{array}$ & $\begin{array}{c}-0,31 \\
(-0,08)\end{array}$ & $\begin{array}{l}-1,56 \\
(-0,50)\end{array}$ & $\begin{array}{c}-0,13 \\
(-0,05)\end{array}$ & $\begin{array}{l}-0,23 \\
(-0,09)\end{array}$ & $\begin{array}{c}-0,55 \\
(-0,23)\end{array}$ & $\begin{array}{c}-0,17 \\
(-0,07)\end{array}$ & $\begin{array}{c}-0,53 \\
(-0,24)\end{array}$ & $\begin{array}{c}2,09 \\
(1,03)\end{array}$ & $\begin{array}{c}4,64 \\
(2,40)\end{array}$ & $\begin{array}{c}4,35 \\
(2,31)\end{array}$ & $\begin{array}{c}3,60 \\
(1,99)\end{array}$ & $\begin{array}{c}2,73 \\
(1,55)\end{array}$ & $\begin{array}{c}3,87 \\
(2,27)\end{array}$ & $\begin{array}{c}3,54 \\
(2,15)\end{array}$ & $\begin{array}{c}3,67 \\
(2,35)\end{array}$ & $\begin{array}{c}3,61 \\
(2,38)\end{array}$ & $\begin{array}{c}3,67 \\
(2,47)\end{array}$ \\
\hline
\end{tabular}

\section{Appendix F. Line Graph of Grrealndaq}

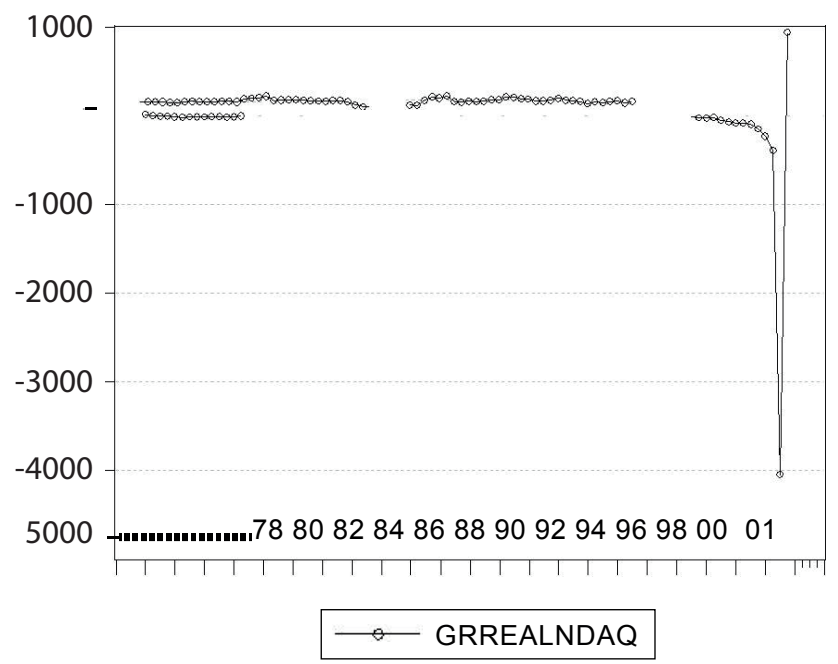




\section{References}

ALESINA, A. (1987), "Macroeconomic Policy in a Two-Party System as a Repeated Game”, Quarterly Journal of Economics, 102, 650-678.

ALESINA, A., Cohen, G.D. and Roubini, N. (1992), "Macroecomic Policy and Elections in OECD Democracies. Centre for Economic Policy Research, Discussion Paper No. 608.

ALESINA, A., Cohen, G.D. and Roubini, N. (1997), Political Cycles and the Macroeconomy, Cambridge, Mass. (USA): The MIT Press.

BERGER, H. and Woitek, U. (1997), "Searching for Political Business Cycles in Germany”, Public Choice, 91, 2, 179-97.

BERGER, H. and Woitek, U. (1999), Further Observations on the Political Business Cycle in German Monetary Aggregates, CES, University of Munich and University of Glasgow.

BERGER, H. and Woitek, U., (2001), “The German political business cycle: money demand rather than monetary policy" European Journal of Political Economy $17,3,609-631$.

BLOCK, S. A. (2002), Political Business Cycles, Democratization, and Economic Reform: The Case of Africa, Journal of Development Economics, 67, 1, 205228.

BOX G., Jenkins, G. (1976), Time Series Analysis, Forecasting, and Control. San Francisco, Calif. Holden Day.

CAMERON, L. and Crosby, M. (2000), "It's the Economy Stupid: Macroeconomics and Federal Elections in Australia", The Economic Record, Vol. 76, No. 235, (354-364).

CAMPBELL, J.Y. and Perron, P. (1991), "Pittfalls and Opportunities: What Macroeconomists Should Know About Unit Roots”, National Bureau of Economic Research, Technical Working Paper No: 100.

DOWNS, A. (1957), An Economic Theory of Democracy, New York: Harper \& Row.

ENDERS, W. (1995), Applied Econometric Time Series, USA and Canada: John Wiley \& Sons, Inc.

EREN, E. and Bildirici, M. (1999), "Siyasal Konjonktür Dalgaları ve Türkiye’de Seçmen Davranışı”. İktisat, İşletme ve Finans Dergisi, Ekim, 27-37.

ERGUN, M. (2000), Electoral Political Business Cycles in Turkey, Thesis (Master's) Bilkent University.

ERSEL, H. and Öztürk, E. (1992), Para Politikası Uygulamaları ve Para Miktarı, TCMB Araştırma Genel Müdürlüğü, Tartışma Tebliği, 9207.

HALL, A. (1994) Testing for a unit root in time series with pretest data-based model selection, Journal of Business and Economic Statistics, 12, 461-70. 
HALlERBERG, M. and Souza, L. V. (2000), “The Political Business Cycles of EU Accession Countries”, Tinbergen Institute Discussion Paper, TI 2000-085/2.

HIBBS, D. (1977), "Political Parties and Macroeconomic Policy", American Political Science Review, 71, 1466-1487.

KYDLAND, F. and Prescott, E. (1977), "Rules Rather than Discretion: The Inconsistency of Optimal Plans, Journal of Political Economy, 85, 473-90.

KUZU, Y. (2001), Türkiye Ekonomisinde Politik Devresel Hareketler, Yüksek Lisans Tezi, Ankara Üniversitesi Sosyal Bilimler Enstitüsü.

LEERTOUWER, E. and Maier, P. (2000) International and Domestic Constraints on Political Business Cycles in OECD Economies: A Comment, University of Groeningen.

LEERTOUWER, E. and Maier, P. (2001), "Who creates political business cycles: should central banks be blamed?", European Journal of Political Economy, $17,3,445-463$.

LOCKWOOD, B., Philippopoulos, A. and Tzavalis, E., (2001) "Fiscal policy and politics: theory and evidence from Greece 1960-1997", Economic Modelling, $18,2,253-268$.

MACKINNON, J. G. (1991), Critical Values for Cointegration Tests. In: R. F. Engle and C. W. J. Granger (Eds.) Long-run Economic Relationships: Readings in Cointegration, Oxford University Press, Oxford. pp.267-276.

MUTH, J.F. (1961), "Rational Expectations and the Theory of Price Movements", Econometrica, 29, 3, 315-335.

NELSON, C.R. and Plosser, C.I. (1982), “Trends and Random Walks in Macroeconomic Time Series: Some Evidence and Implications, Journal of Monetary Economics, 10, 139-162.

NORDHAUS, W. (1975), “The Political Business Cycle”, The Review of Economic Studies, 42, 169-191.

OLTERS, J.P. (2001), "Modeling Politics with Economic Tools: A Critical Survey of the Literature", IMF Working Papers, WP/01/10.

ÖZATAY, F. (1999), "Populist Policies and the Role of Economic Institutions in the Performance of Turkish Economy", Yapı Kredi Economic Review, 10, 1.

ÖZATAY, F (2000), Public Price Controls, Deficit Financing, and Electoral Cycles, A Paper Presented at METU Conference in Economics in Sept. 13-16.

ÖZTÜRK, E. (1992), Türkiye'de Son Dönemde Para Politikası Tartışmaları, TCMB Araştırma Genel Müdürlüğü, Tartışma Tebliği, 9206.

PALDMAN, M. (1997), “Political Business Cycles”, in Mueller 1997 (ed.) Perspectives of Public Choice.

PERRON, P. (1989), “The Great Crash, the Oil Price Shock, and the Unit Root Hypothesis, Econometrica, 57, 1361-1401. 
PERSSON, T. and Tabellini, G. (1990), Macroeconomic Policy, Credibility and Politics, New York: Harwood Academic Publishers.

PHILLIPS, A. W. (1958), “The Relation between Unemployment and the Rate of Change of Money Wages in the United Kingdom, 1861-1957”, Economica, 25, 100, 283-299.

PITRUZELlO, S. (1999), "Political Business Cycles and Independent Central Banks. German Governments and the Bundesbank (1960-1989), EUI Working Paper RSC No. 99/7.

ROGOFF, K. and Sibert, A. (1988), "Elections and Macroeconomic Policy Cycles", Review of Economic Studies, 55, 1-16

SCHUMPETER, J. (1945), Capitalism and Democracy, New York: Harper, 1945.

TELATAR, F. (2001), "Politik Devresel Dalgalanmalar Teorisi Iş1 ğında Demokrasi-Siyaset-Ekonomi İlişkisi”, İktisat, İşletme ve Finans, 16, 187, 57-66.

TREISMAN, D. and Gimpelson, V. (1999), "Political Business Cycles and Russian Elections, or the Manipulations of "Chudar"”, CIRJE-F-39.

TUTAR, İ. and Tansel, A. (2000), Political Business Cycles, Institutional Structure and Budget Deficits in Turkey, A Paper Presented at METU Conference in Economics in September 13-16, 2000.

WEBER, C. E. (2001), “Alternative Lag Length Selection Criteria and the SplitTrend Stationarity Hypothesis”, Applied Economics, 33, 237-247.

YAMAK, N. and Yamak, R. (1999), “Türkiye'de Genel Milletvekili Seçimleri ve Ekonomi”, İktisat, İşletme ve Finans Dergisi, Şubat, 47-57.

ZIVOT, E. and Andrews, D. (1992), "Further Evidence on the Great Crash, the Oil Price Shock and the Unit Root Hypothesis, Journal of Business and Economics Statistics, 10, 251-270. 
